Provided for non-commercial research and education use. Not for reproduction, distribution or commercial use.

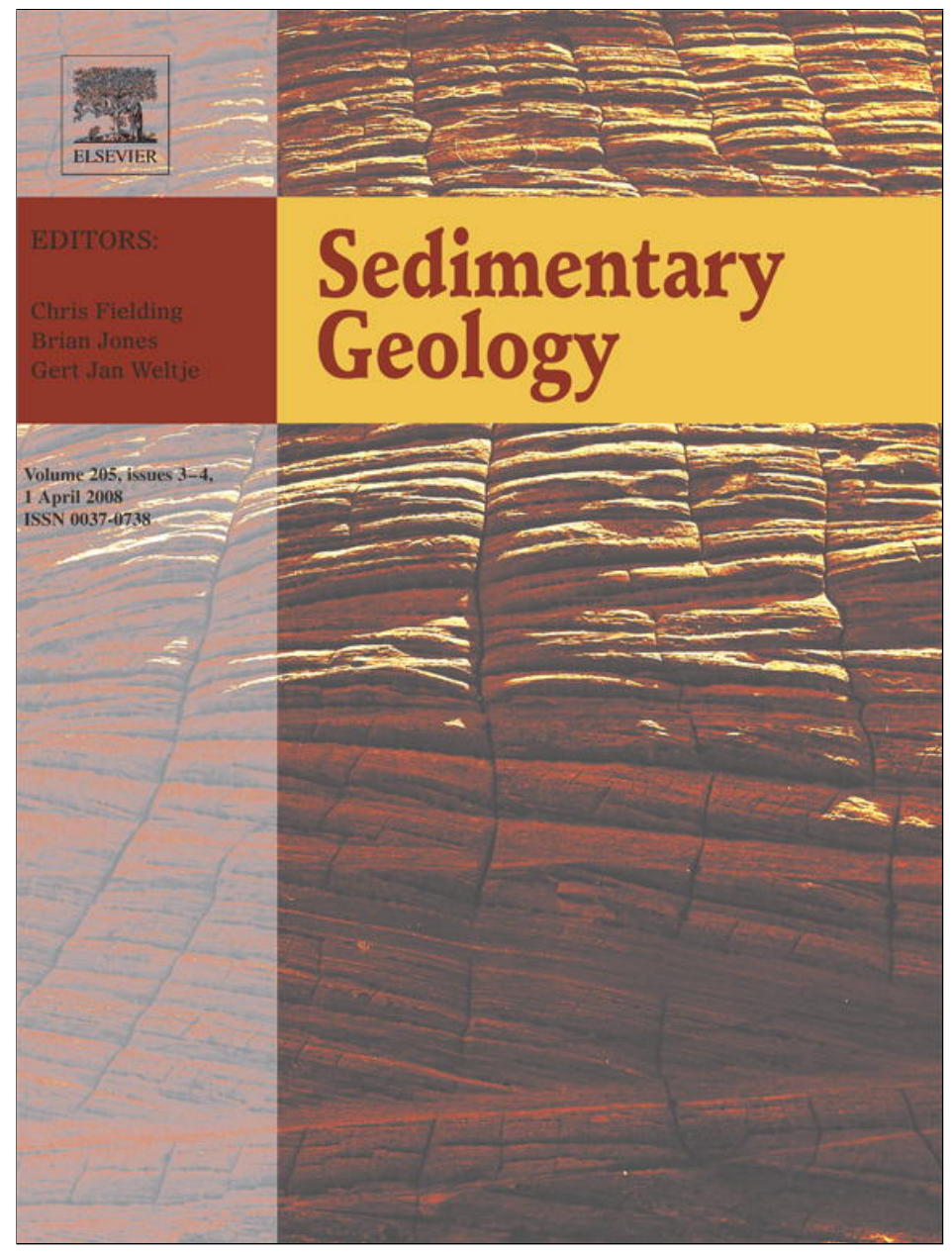

This article appeared in a journal published by Elsevier. The attached copy is furnished to the author for internal non-commercial research and education use, including for instruction at the authors institution and sharing with colleagues.

Other uses, including reproduction and distribution, or selling or licensing copies, or posting to personal, institutional or third party websites are prohibited.

In most cases authors are permitted to post their version of the article (e.g. in Word or Tex form) to their personal website or institutional repository. Authors requiring further information regarding Elsevier's archiving and manuscript policies are encouraged to visit:

http://www.elsevier.com/copyright 


\title{
Demise of the northern Tethyan Urgonian carbonate platform and subsequent transition towards pelagic conditions: The sedimentary record of the Col de la Plaine Morte area, central Switzerland
}

\author{
Karl B. Föllmi* , François Gainon \\ Geological Institute, University of Neuchâtel, Rue Emile Argand 11, 2009 Neuchâtel, Switzerland
}

\section{A R T I C L E I N F O}

\section{Article history:}

Received 28 October 2007

Received in revised form 16 February 2008

Accepted 21 February 2008

\section{Keywords:}

Cretaceous

Col de la Plaine Morte

Helvetic Zone

Switzerland

Urgonian platform drowning

Selli event

\begin{abstract}
A B S T R A C T
The sedimentary succession of the Col de la Plaine Morte area (Helvetic Alps, central Switzerland) documents the disappearance of the northern Tethyan Urgonian platform in unprecedented detail and suggests stepwise platform demise, with each drowning phase documented by erosion and phosphogenesis. The first identified drowning phase terminated Urgonian carbonate production in a predominantly photozoan mode. Using a correlation of the whole-rock $\delta^{13} \mathrm{C}$ record with the well-dated record from SE France, its age is inferred to as Middle Early Aptian (near the boundary between the weissi and deshayesi zones). A subsequent drowning phase is dated by ammonites and by a correlation of the whole-rock $\delta^{13} \mathrm{C}$ record as Late Early Aptian (late deshayesi to early furcata zone). A third drowning phase provides an ammonite-based age of Early Late Aptian (subnodosocostatum and melchioris zones) and is part of a widely recognized phase of sediment condensation and phosphogenesis, which is dated as latest Early to Middle Late Aptian (late furcata zone to near the boundary of the melchioris and nolani zones). The fourth and final drowning phase started in the latest Aptian (jacobi zone) as is also indicated by ammonite findings at the Col de la Plaine Morte. The phases of renewed platform-carbonate production intervening between the drowning phases were all in a heterozoan mode. During the ultimate drowning phase, phosphogenesis continued until the Early Middle Albian, whereas condensation processes lasted until the Middle Turonian. Coverage of the external margin of the drowned Urgonian platform by a drape of pelagic carbonates started only in the Late Turonian. During the Santonian, the external part of the drowned platform underwent normal faulting and saw the re-exposure of already lithified Urgonian carbonates at the seafloor.

Based on the here-inferred ages, the first drowning phase just precedes oceanic anoxic episode 1a (OAE 1a or "selli event") in time, and the second drowning phase partly overlaps with OAE 1a. The onset of the third drowning event slightly predates two further periods of increased organic-matter accumulation in the Vocontian Basin (Noir and Fallot levels), and the onset of the fourth and final drowning phase may coincide with two further periods of increased organic-matter accumulation in the Vocontian Basin (Jacob and Kilian levels, part of OAE 1b). These correlations indicate a relationship between the so-called anoxic episodes and the stepwise demise of the Urgonian platform, even if the onset of environmental change is registered earlier on the platform than in basinal sediments.
\end{abstract}

(c) 2008 Elsevier B.V. All rights reserved.

\section{Introduction}

The Late Early to Early Late Cretaceous witnessed a suite of recurrent oceanic anoxic episodes, which was unique for the entire Mesozoic and Cenozoic if one considers its frequency and multiple impact on the environment (e.g., Schlanger and Jenkyns, 1976; Arthur and Schlanger, 1979; Jenkyns, 1980; Leckie et al., 2002). The "mid"Cretaceous anoxic episodes are an expression of major environmental change during this period, for which its manifestation was not limited

\footnotetext{
* Corresponding author. Tel.: +41 3271826 55; fax: +41 327182601

E-mail address: karl.foellmi@unine.ch (K.B. Föllmi).
}

to ocean basins, but extended also onto the adjacent shelves and continents (e.g., Schlager and Philip, 1990; Gröcke et al., 1999).

Multiple links have been proposed between chemical and environmental change on the continents, the shelf regions and deeper basins during these episodes, such as increased methane release from slope sediments (Wissler et al., 2003), ocean acidification (Weissert and Erba, 2004) and increased nutrient input from continents (Erba, 1994; Föllmi et al., 1994). These interpretations are all dependent on positive correlations between the numerous proxies of environmental change in the different compartments. Their precision is, however, often hampered by the lack of convincing bio- or chemostratigraphic time control. 
The sedimentary remains of a vast shallow-water carbonate platform attached to the northern Tethyan shelf and presently locked up in the Helvetic Alps have been revealed to have sensitively recorded paleoenvironmental change during the latest Jurassic and Early Cretaceous (Funk et al., 1993; Föllmi et al., 1994, 2006, 2007). They have furthermore the advantage that time control by ammonite stratigraphy is good, and as such they provide valuable insight into the effects of environmental change associated with the anoxic episodes.

During the evolution of this platform, a phase of important platform progradation and aggradation has been recognized, which resulted in the buildup of a prominent and predominantly photozoan carbonate succession - the so-called "Urgonian" (e.g., Lienert, 1965; Arnaud-Vanneau et al., 1976; Funk et al., 1993; Michalik, 1994; Arnaud et al., 1998; Bernaus et al., 2003; Bodin et al., 2006a; Godet et al., submitted for publication). Coeval sediments of equivalent or at least comparable facies are also documented from the Arabian peninsula (e.g., Immenhauser et al., 2004) and from the Cupido carbonate platforms of northeastern Mexico (Bralower et al., 1999; Lehmann et al., 1999; cf. also Ager, 1981). Along the northern Tethyan margin, the onset of Urgonian platform growth is dated as Late Barremian (e.g., ArnaudVanneau et al., 1976; Arnaud et al., 1998; Bodin et al., 2006a; Föllmi et al., 2006, 2007; Godet et al., submitted for publication). The demise of the Urgonian platform appears to be diachronous: whereas in western and central Europe its disappearance is dated as Early Aptian (e.g., Arnaud et al., 1998), in eastern Europe this facies appears to continue well into the Albian (e.g., Michalik, 1994). Repeated interferences between environmental change, the "mid"-Cretaceous oceanic anoxic episodes and the evolution of the Urgonian platform in general are highly likely and may explain the ultimate disappearance of this platform system (e.g., Föllmi et al., 2006, 2007).

Once drowned, the platform sediments of the northern Tethyan margin became covered by a mixture of detrital, glauconite and phosphate-rich sediments, which often show the influence of sedimentary condensation processes (Heim and Seitz, 1934; Heim, 1934; Schaub, 1936; Föllmi, 1986, 1989, 1990; Föllmi and Ouwehand, 1987; Ouwehand, 1987; Delamette, 1988; Delamette et al., 1997). Subsequently, the external part of the northern Tethyan margin experienced a transition to more pelagic conditions.

The stratigraphic succession exposed in the Col de la Plaine Morte area (Helvetic Alps of central Switzerland; Fig. 1) is in so far unique in that it embodies one of the most complete successions for the Early Aptian hitherto documented from the northern alpine Helvetic Zone. This succession reveals the history of the drowning of the Urgonian platform in unprecedented detail, and the combination of new ammonite findings and a whole-rock $\delta^{13} \mathrm{C}$ record allows to infer precise ages for each drowning step and to improve their correlation with the Early Aptian anoxic episode OAE 1a ("Selli event").

Furthermore, this succession shows very nicely how the drowned platform was consequently subjected to a persistent phase of condensation and phosphogenesis, which lasted for approximately 30 million years and terminated during the Middle Turonian. The excellent outcrop conditions allow for the observation of sedimentological and biostratigraphic details which elucidate how this condensation phase proceeded. Finally, a sheet of pelagic carbonate covered the drowned platform and its topography became accentuated by the emplacement of normal fault structures.

The goal of this contribution is therefore to document the outcrops at the Col de la Plaine Morte in detail and to trace each drowning step and the period following the final drowning phase, and precisely document its sedimentological and chronostratigraphic context, wherever available.

\section{The Col de la Plaine Morte area}

The region of the Col de la Plaine Morte is part of the Helvetic thrust-and-fold belt of the northern Alps of central Switzerland (Wildhorn nappe; Fig. 1). It exposes a succession of Cretaceous and
Eocene marine sedimentary rocks, which are representative for the external part of the northern Tethyan margin (Fig. 2). This succession includes a nicely differentiated, fairly complete, and remarkably wellexposed series of Late Early to Late Cretaceous age (Figs. 3, 4, and 5), which has been the subject of different publications and theses: Lugeon (1918) published a first detailed description of the tectonic context of this region, and was the first to recognize the presence of synsedimentary, normal faults in sediments of Late Cretaceous age. Schaub $(1936,1948)$ gave a first detailed compilation of the stratigraphy of this area and proposed a sedimentary model for the genesis of the condensed phosphate-rich beds of Aptian to Turonian age (Plattenwald Bed, see below), in which reworking and lateral transport were important mechanisms. Schenk (1992) investigated the Barremian Tierwis Formation (formerly Drusberg Formation; Föllmi et al., 2007) and Urgonian Schrattenkalk Formation with regard to their lithology, facies and age. Based on orbitolinid biostratigraphy (by R. Schroeder, Frankfurt), she postulated an Early Barremian age for the onset of the Schrattenkalk Formation, thereby placing the subjacent Drusberg Member in the Late Hauterivian or earliest Barremian; she also attributed an latest Aptian-Early Albian age for the top of the Schrattenkalk Formation. These postulated ages are not compatible with current age models for these formations (Bollinger, 1988; Föllmi et al., 2007; Fig. 4), and this discrepancy provided us with an incentive to explore the stratigraphic succession of the Col de la Plaine Morte area in more detail.

\section{Methods}

Stratigraphic sections were examined, measured and sampled during the late summers of the last 15 years, during periods when the snow cover was minimal. Late summer 2003 was characterized by exceptional warm and dry weather conditions and allowed the examination of outcrops, which are normally covered by snow. Samples were cut and polished, and thin sections were systematically prepared.

Stable carbon and oxygen isotope analyses were performed on powdered samples at the University of Berne using a VG Prism II ratio mass spectrometer equipped with a common acid bath $\left(\mathrm{H}_{3} \mathrm{PO}_{4}\right)$. The results were calibrated to the PDB scale with standard errors of $0.1 \%$ 。 for $\delta^{18} \mathrm{O}$ and $0.05 \%$ or for $\delta^{13} \mathrm{C}$.

Scanning electron micrographs were taken at the Center of Electronic Nanno- and Microscopy, University of Neuchâtel, using an environmental SEM (Philips XL30) and a conventional SEM (Philips XL20).

\section{Stratigraphy}

\subsection{Kieselkalk Formation (Hauterivian)}

The approximately $200 \mathrm{~m}$ thick Kieselkalk Formation in the area north of the Col de la Plaine Morte consists of two coarsening-upward successions which are each characterized by a marly base which progressively passes into a well-bedded, crinoidal and spiculitic limestone (Fig. 2). The top of the upper succession is composed of a 1.5$2 \mathrm{~m}$ thick interval of coarse-grained, glauconite-containing, crinoidal limestone (Schaub, 1936; Gainon, 2001). The two successions are dated by correlation to fossiliferous outcrops in central and eastern Switzerland: the lower succession covers the middle part of the Early Hauterivian (loryi to nodosoplicatum zones), whereas the upper succession is attributed to the Middle Late Hauterivian (ligatum to angulicostatum zones; Kuhn, 1996; Van de Schootbrugge, 2001; Van de Schootbrugge et al., 2003; Bodin et al., 2006b).

\subsection{Tierwis Formation (latest Hauterivian to Early Late Barremian)}

4.2.1. Altmann Member (latest Hauterivian to Late Early Barremian)

The Altmann Member follows directly on top of the Kieselkalk Formation and starts with a thin (approximately $0.1 \mathrm{~m}$ ) limestone bed 

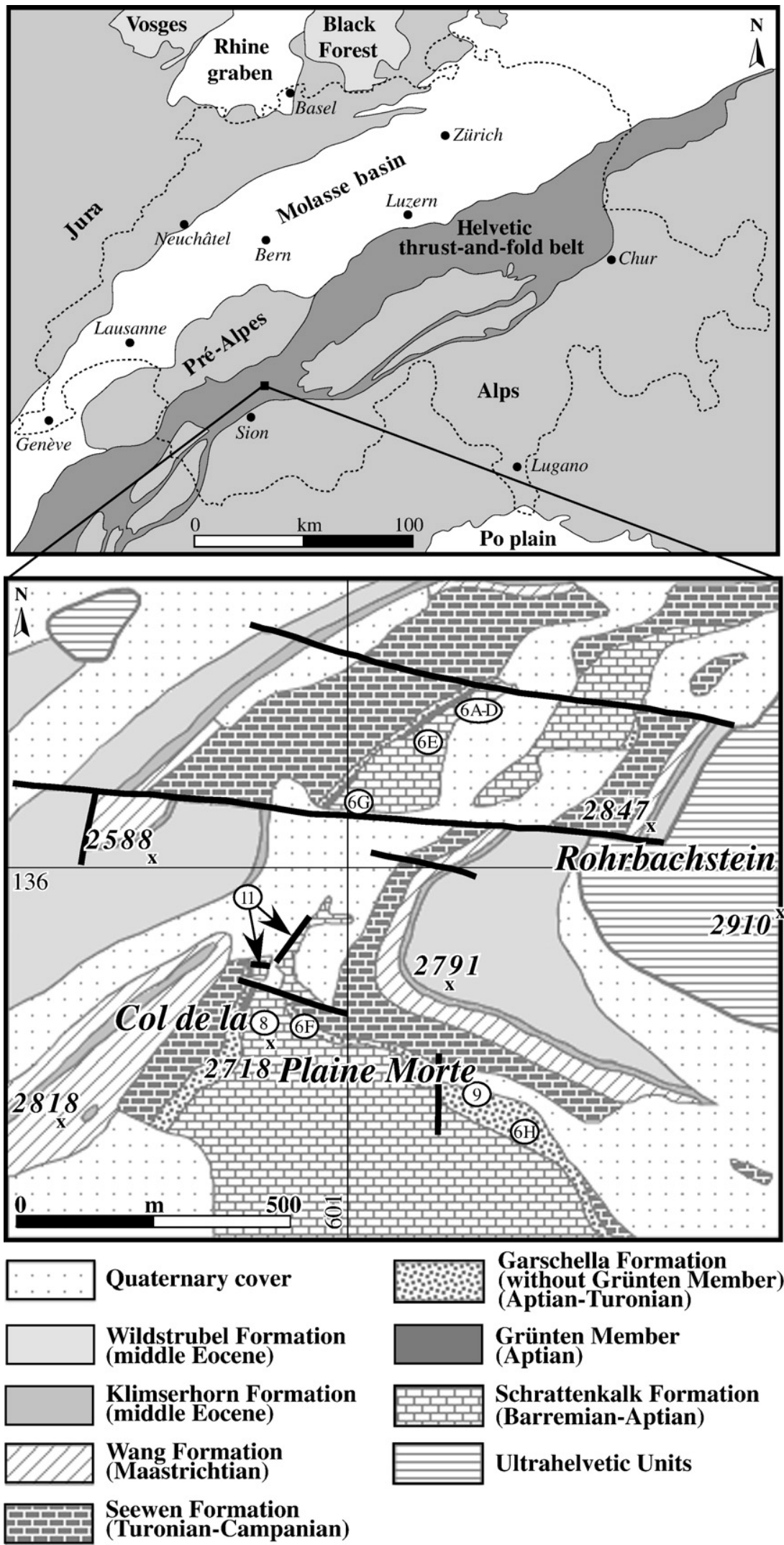

Quaternary cover

Wildstrubel Formation (middle Eocene)

Klimserhorn Formation (middle Eocene)

\section{Wang Formation}

(Maastrichtian)

Seewen Formation

(Turonian-Campanian)

Fig. 1. Tectonic overview of Switzerland with indication of the location of the Col de la Plaine Morte area. The geological map is an excerpt from a geological map by Gainon (2001). The general tectonic overview is after Bodin et al. (2006b). Labeled oval insets indicate exact locations of photographed outcrops and samples in Figs. 6 , 8, 9, and 11. Arrows point to the two synsedimentary normal faults described in this contribution (Gainon, 2001; Fig. 11).

rich in phosphate nodules, partly silicified belemnites, quartz, and glauconite (Fig. 2). This bed is overlain by a 3-4 $\mathrm{m}$ thick succession of glauconite-bearing marl and limestone, which is rich in small fish teeth at the top. A good outcrop is present NE of Graui Felse (CHCoord.: 600.825/137.125) Schaub, 1936; Gainon, 2001; Bodin et al. 2006b). Recently, Bodin et al. (2006b) gave a precise age for central 
and eastern Swiss and western Austrian occurrences of the Altmann Member, which is used for this occurrence by extrapolation: the Altmann Member spans the time interval between the angulicostatum zone (latest Hauterivian) and darsi zone (latest Early Barremian).

\subsubsection{Drusberg Member (Early Late Barremian)}

The Drusberg Member consists of a coarsening-upward succession of well-bedded spiculitic carbonates rich in crinoids and bivalves, alternating with marls (minimally $30 \mathrm{~m}$ in thickness). Its latest Early to Early Late Barremian (darsi to sartousiana zone) age is determined by benthic foraminifera, rare ammonites, and the age of the underlying
Altmann Member and the Chopf Bed which is overlying this member in eastern Switzerland (Bollinger, 1988; Bodin et al., 2006a). The age proposed by Schenk (1992) for the onset of this member (latest Hauterivian or earliest Barremian; based on orbitolinid biostratigraphy; determination: R. Schroeder, Frankfurt; Fig. 4) cannot be accepted.

\subsection{Urgonian Schrattenkalk Formation (Late Barremian to Early Aptian)}

The Urgonian stage in the development of the carbonate platform of this area has been investigated by Schaub (1936) and Schenk (1992),
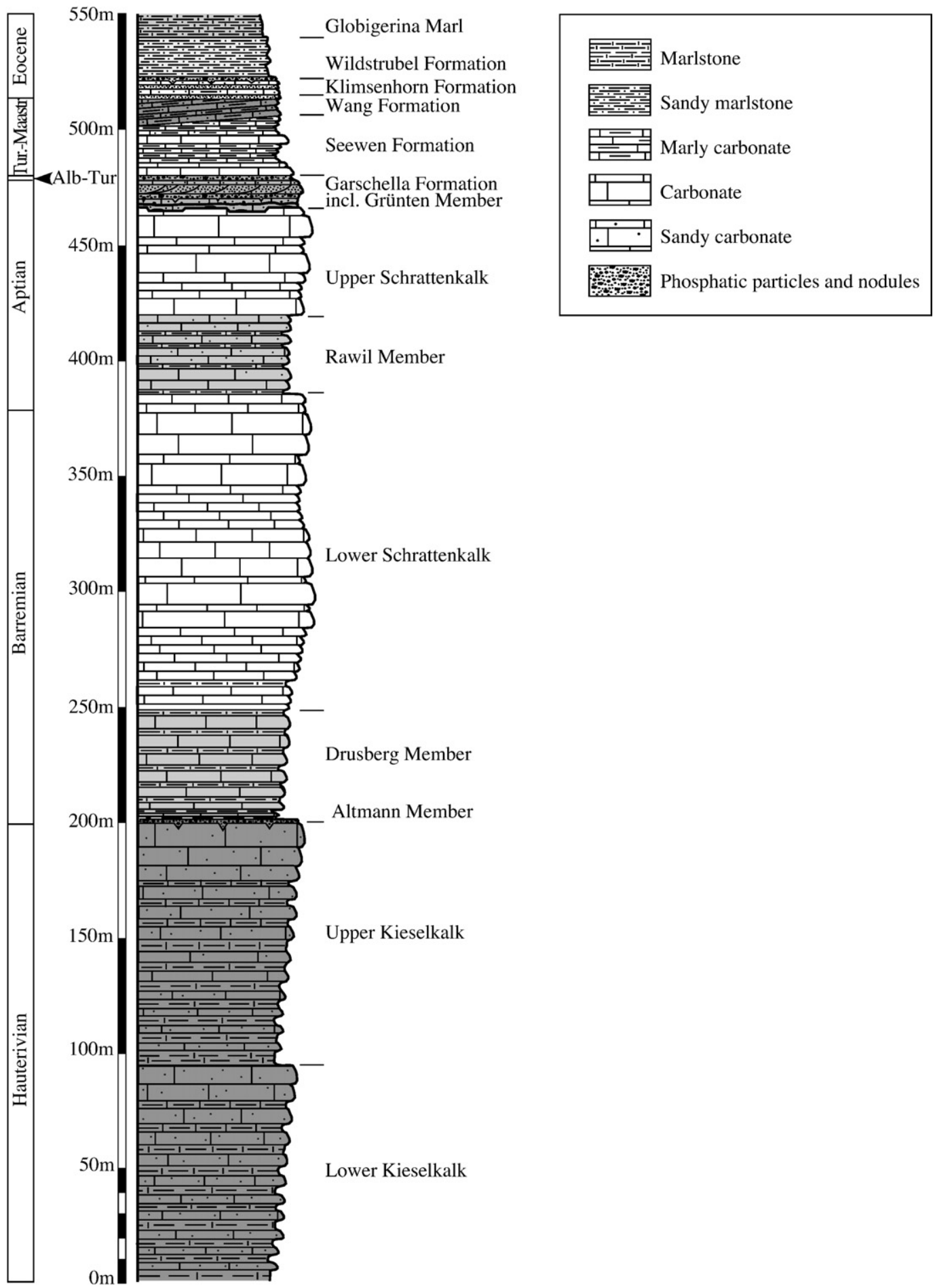

$0 \mathrm{~m}$

Fig. 2. Lithostratigraphic log of the sedimentary succession outcropping in the region of the Col de la Plaine Morte and north of it (modified from Gainon (2001) and Schenk (1992)). 


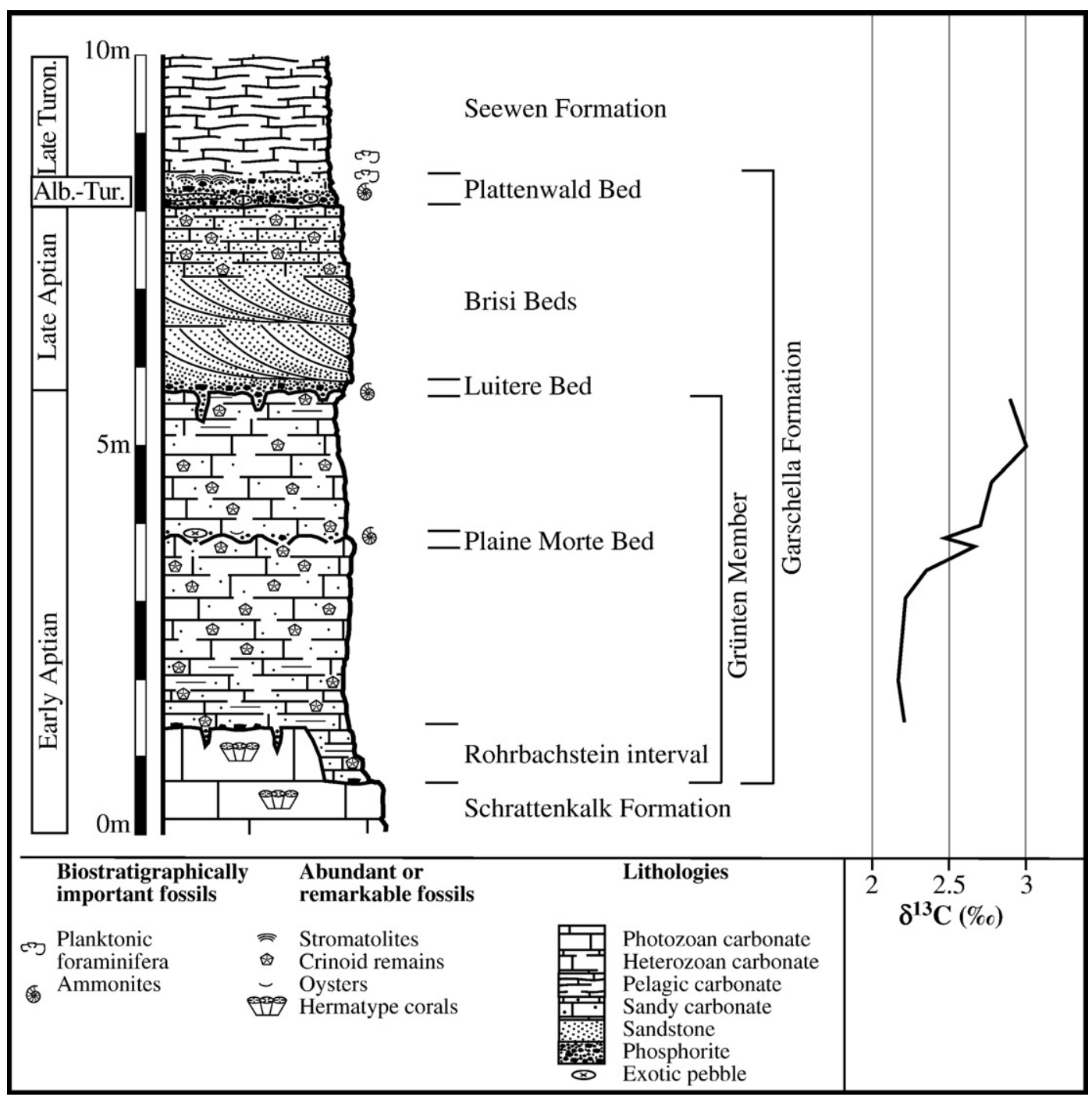

Fig. 3. Lithostratigraphic section of the Garschella Formation in the area NE of the Col de la Plaine Morte and evolution of whole-rock $\delta^{13} \mathrm{C}$ values measured in the Grünten Member (Gainon, 2001).

who both distinguished two phases of platform development (lower and upper Schrattenkalk), which was interrupted by a phase of increased detrital input ("lower Orbitolina Beds" = "Orbitolina Member"; Fig. 2). Schenk proposed the name "Rawil Beds" for this member and this name has recently been retained as the official name for this member in the Helvetic Zone (cf. Föllmi et al., 2007). The lower Schrattenkalk is composed of approximately $150 \mathrm{~m}$ of bioclastic and oolitic limestone, which includes increasing amounts of rudist and coral remains towards the top. The Rawil Member consists of approximately $20 \mathrm{~m}$ of well-bedded limestone and marly limestone, and the upper Schrattenkalk is represented by $30-50 \mathrm{~m}$ of coarsely bedded bioclastic limestone, which is rich in rudists and corals towards the top.

According to orbitolinid biostratigraphy in the upper Schrattenkalk by Schroeder in Schenk (1992), this member extends well into the Late Aptian (for the area immediately north of the Col de la Plaine Morte) and maybe even into the Early Albian (for the Interlaken area). New ammonite findings in the overlying Grünten Member (= "upper Orbitolina Beds") and the Luitere Bed in the Col de la Plaine Morte area, however, do not confirm the orbitolinid-derived ages (see below) and place a Middle Early Aptian age (top weissi zone) as upper age limit for the upper Schrattenkalk.

\subsection{Garschella Formation (Late Early Aptian to Middle Turonian)}

4.4.1. Grünten Member (“upper Orbitolina Beds”; Late Early Aptian)

The Grünten Member (= "upper Orbitolina Beds"; Linder et al., 2006) occurs only locally in the form of lenticular bodies (max. $5 \mathrm{~m}$ thick, min. several $100 \mathrm{~m}$ long), as was already noted by Schaub (1936). A first occurrence is present approximately $800 \mathrm{~m}$ NNE of the Col de la Plaine Morte (CH-coordinates: 601.100/136.200; Fig. 3) and a second occurrence is located on the western flank of the Col de la Plaine Morte (CH-coordinates: 600.700/135.700; Gainon, 2001). In places where sediments of the Grünten Member are present, the contact to the underlying upper Schrattenkalk Member is a clear-cut unconformity, characterized by the local presence of high-angle incisions, angular discontinuities, and fissure infills (Fig. 6A). The top surface of the upper Schrattenkalk is marked by patchy phosphatic mineralisations (Fig. 5B). This phase of macroscopic phosphate precipitation correlates to a phase of phosphogenesis and glauconitization, which is materialized in a thin layer rich in glauconite at the base of the Grünten Member in the Helvetic Alps of central Switzerland and Allgäu, and which is named Rohrbachstein Bed (Föllmi et al., 2007). The type locality is the here-described outcrop NNE of the Col de la Plaine Morte, west of the Rohrbachstein (Fig. 1). 


\begin{tabular}{|c|c|c|}
\hline Lithostratigraphy & Orbitolinid biostratigraphy & Ammonite biostratigraphy \\
\hline Plattenwald Bed & & $\begin{array}{l}\text { Hypacanthoplites } \\
\text { Leymeriella } \\
\text { Douvilleiceras } \\
\text { (latest Aptian - early Albian) }\end{array}$ \\
\hline \multicolumn{3}{|l|}{ Brisi Beds } \\
\hline Luitere Bed & & $\begin{array}{l}\text { Colombiceras } \\
\text { Cheloniceras } \\
\text { (early Late Aptian) }\end{array}$ \\
\hline Grünten Member & & $\begin{array}{l}\text { Aconeceras } \\
\text { Deshayesites } \\
\text { (middle Early Aptian) }\end{array}$ \\
\hline $\begin{array}{c}\text { Upper } \\
\text { Schrattenkalk } \\
\text { Member }\end{array}$ & $\begin{array}{l}\text { Orbitolina (texana)-subconcava } \\
\text { Pseudochoffatella cuvillieri } \\
\text { Coskinolinella santanderensis } \\
\text { (Late Aptian, ev. earliest Albian) }\end{array}$ & \\
\hline $\begin{array}{l}\text { Rawil } \\
\text { Member }\end{array}$ & $\begin{array}{l}\text { Palorbitolina lenticularis } \\
\text { Paracoskinolina maynci } \\
\text { Cribellopsis neoelongata } \\
\text { (Earliest Aptian, ev. latest Barremian) }\end{array}$ & \\
\hline $\begin{array}{c}\text { Lower } \\
\text { Schrattenkalk } \\
\text { Member }\end{array}$ & $\begin{array}{l}\text { Paleodictyonus cuvillieri } \\
\text { Paracoskinolina reicheli } \\
\text { Paracoskinolina maynci } \\
\text { (Earliest Barremian) }\end{array}$ & \\
\hline $\begin{array}{l}\text { Drusberg } \\
\text { Member }\end{array}$ & $\begin{array}{l}\text { Paleodictyonus cuvillieri } \\
\text { Cribellopsis elongata } \\
\text { Paracoskinolina reicheli } \\
\text { Urgonina alpillensis } \\
\text { (Earliest Barremian, ev. latest Hauterivian) }\end{array}$ & $\begin{array}{l}\text { top Drusberg Member: } \\
\text { sartousiana zone } \\
\text { (middle Late Barremian) } \\
\text { Bodin et al., 2006a }\end{array}$ \\
\hline $\begin{array}{l}\text { Altmann } \\
\text { Member }\end{array}$ & $\begin{array}{l}\text { Paleodictyonus cuvillieri } \\
\text { Cribellopsis elongata } \\
\text { (Earliest Barremian) }\end{array}$ & $\begin{array}{l}\text { seitzi- to darsi Zone } \\
\text { (late Hauterivian - } \\
\text { latest Early Barremian) } \\
\text { Bodin et al., 2006b }\end{array}$ \\
\hline
\end{tabular}

Fig. 4. Biostratigraphies of the upper lower Cretaceous succession of the Col de la Plaine Morte region based on orbitolinids (by Schroeder in Schenk, 1992) and based on ammonites, which were found during this study in the region of the Col de la Plaine Morte or ammonite-based stratigraphies, which were recently published from the same members in central and eastern Switzerland (Bodin et al., 2006a,b).

The sediments of the Grünten Member consist of a sandy and glauconite-bearing carbonate rich in crinoidal remains, bryozoans, and benthic foraminifera, which is marly at its base. The detrital and

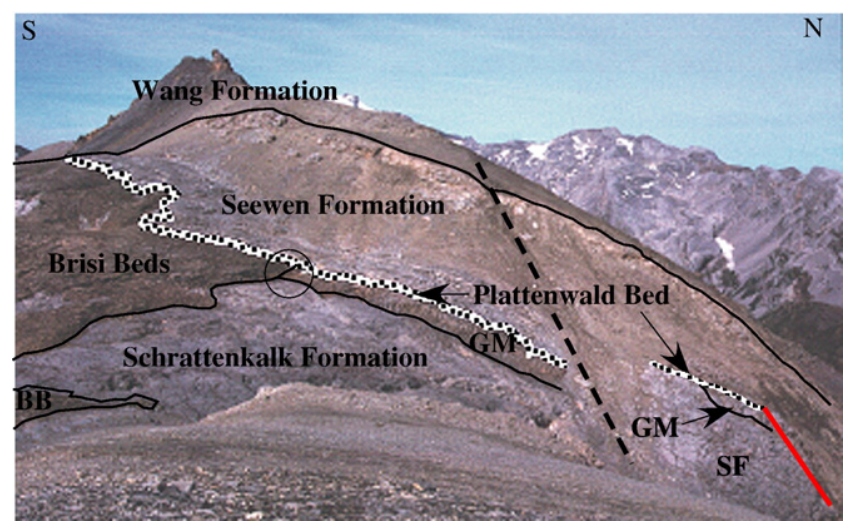

Fig. 5. Geology of the Col de la Plaine Morte. Circle indicates the locality of the steep erosional interface between sediments of the Grünten Member and overlying Brisi Beds shown in more detail in Fig. 8. The red line indicates the location of a synsedimentary fault associated with breccia shown more in more detail in Fig. 11. BB = Brisi Beds, GM = Grünten Member, SF = Schrattenkalk Formation. (For interpretation of the references to colour in this figure legend, the reader is referred to the web version of this article.) glauconite content diminishes towards the top and carbonate contents rise from around 50\% to 90\% (Gainon, 2001). Within the Grünten Member, a phosphatic bed occurs, which is rich in up to $15 \mathrm{~cm}$ large and often irregular carbonate pebbles and cobbles, which are systematically peripherically phosphatized (Fig. 6C). In addition, this bed contains sparse phosphatized particles, oyster remains, belemnites and rare ammonites, amongst which fragments of Deshayesites sp. and Aconoceras nisus (d'Orbigny) (Fig. 7). The Deshayesites fragment is indicative of the deshayesi zone, according to Jean-Pierre Thieuloy (University of Grenoble; personal communication), whereas the A. nisus (d'Orbigny) indicates the furcata and the subnodosocostatum zones, according to Michel Delamette (Chartreuse National Park; personal communication) (Fig. 7). Furthermore, an isolated pebble of crystalline rock (mica schist; Fig. 6D) was found within this phosphatic horizon. Using the ${ }^{40} \mathrm{Ar} /{ }^{39} \mathrm{Ar}$ dating method, Michael Cosca (University of Lausanne; personal communication) obtained an age of approximately $330 \mathrm{Ma}$ (Late Early Carboniferous) on a selection of extracted mica grains. This bed is named Plaine Morte Bed, and its type locality is the outcrop NNE Col de la Plaine Morte, identical with the type locality of the Rohrbachstein Phase or Bed (Föllmi et al., 2007).

In the outcrop NNE of the Col de la Plaine Morte, the lenticular body of the Grünten Member disappears to the west, and the Plaine Morte Bed unifies laterally with the overlying phosphate-rich Luitere Bed (Fig. 5E). 

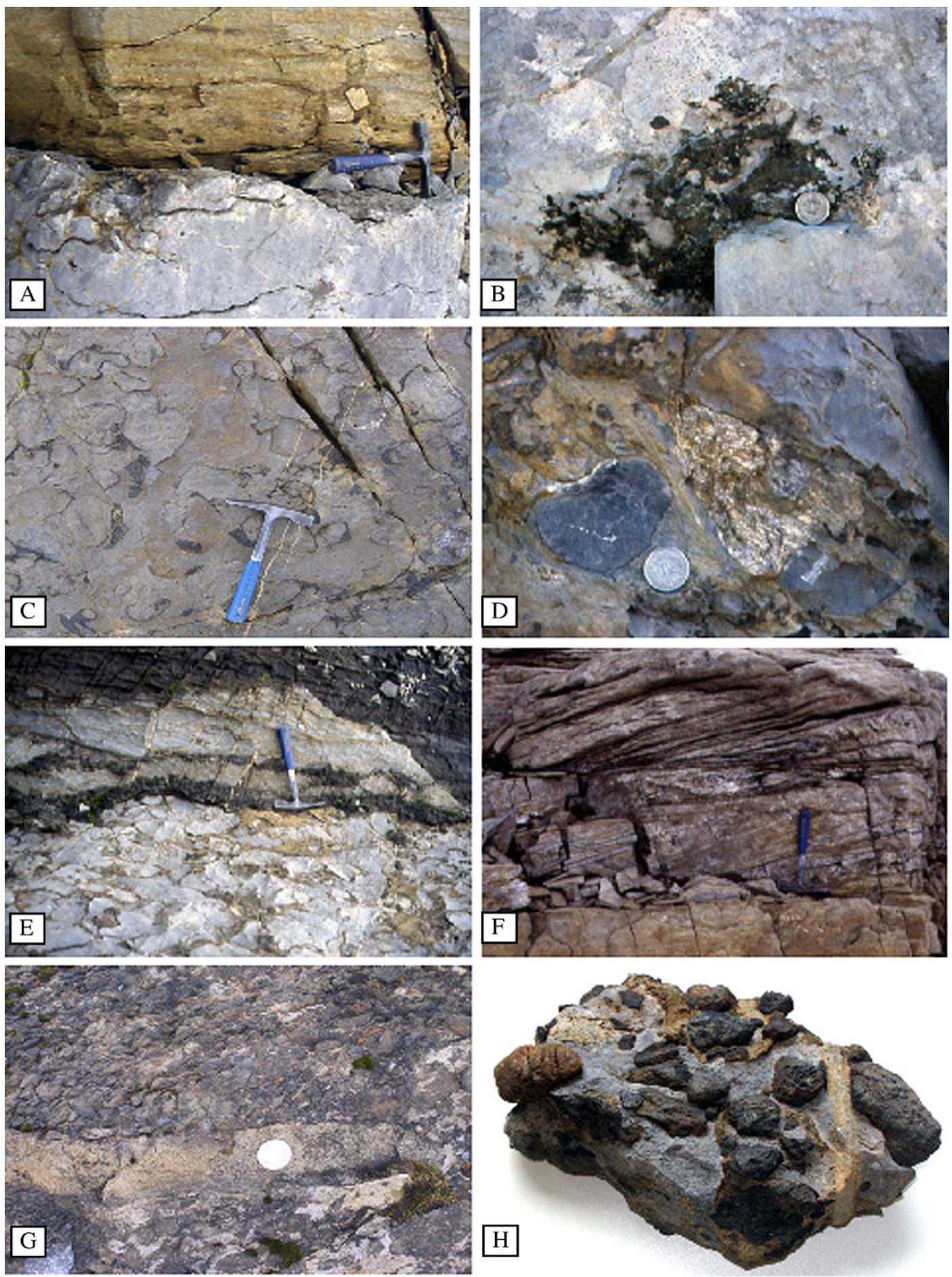

Fig. 6. Photos of outcrops and samples of the Garschella Formation in the area of the Col de la Plaine Morte. The exact locations are indicated in Fig. 1: A. Contact between the whitish neritic photozoan limestone of the Schrattenkalk Formation and the overlying yellowish marly heterozoan limestone of the Grünten Member. Note the irregular top surface of the Schrattenkalk Formation, which is interpreted as a discontinuity surface shaped by erosion during the Rohrbachstein phase; B. A patch of an autochthonous phosphate crust covering the top surface of the Schrattenkalk Formation directly underneath the sediments of the Grünten Member. The here documented phase of phosphogenesis is related to the Rohrbachstein phase, which is inferred to have taken place near the boundary between the weissi and deshayesi zones; C. View on the top surface of the Plaine Morte Bed within the Grünten Member. Note the nodular character of this bed and the peripheral phosphatization of the nodules; D. A unique and exotic subangular pebble consisting of a silver-shining mica schist occurs in the nodular Plaine Morte Bed. The ${ }^{40} \mathrm{Ar} /{ }^{39} \mathrm{Ar}$ age of isolated mica flakes is approximately $330 \mathrm{Ma}$ (coin diameter=2.1 cm); E. Phosphatic nodular Luitere Bed in direct contact with the Plaine Morte Bed. The Luitere Bed is here divided into two separate nodular layers and the bed itself is overlain by coarse-grained sandstone of the Brisi Beds; F. Cross-stratified sandstone at the base of the Brisi Beds, directly on top of the Schrattenkalk Formation; $\mathrm{G}$. Isolated lens (approximately $70 \mathrm{~cm}$ long and $4 \mathrm{~cm}$ thick) consisting of a cross-stratified glauconitic sandstone within the nodular phosphatic Plattenwald Bed, which represents a relic sediment transported in an offshore direction (coin diameter $=2.3 \mathrm{~cm}$ ) (cf. Föllmi, 1996); H. Sample of the Plattenwald Bed showing an exotic yellow-brown quarzite pebble on its left side (pebble length=3.4 cm); the other pebbles and nodules consist of phosphatized fossil debris and sediment. The intervening non-phosphatized sediment is composed of a micritic carbonate comparable to that of the overlying Seewen Formation.

A $\delta^{13} \mathrm{C}$ record was obtained on a selection of whole-rock samples of the Grünten Member in the section NNE of the Col de la Plaine Morte, which shows a rather stable plateau with values of around $2.2 \%$ for the basal $2 \mathrm{~m}$, followed by an increase towards a maximum value of $3 \%$ approximately $1 \mathrm{~m}$ below the top of the Grünten Member (Gainon, 2001; Fig. 3). As these values are approximately in the range of Early 


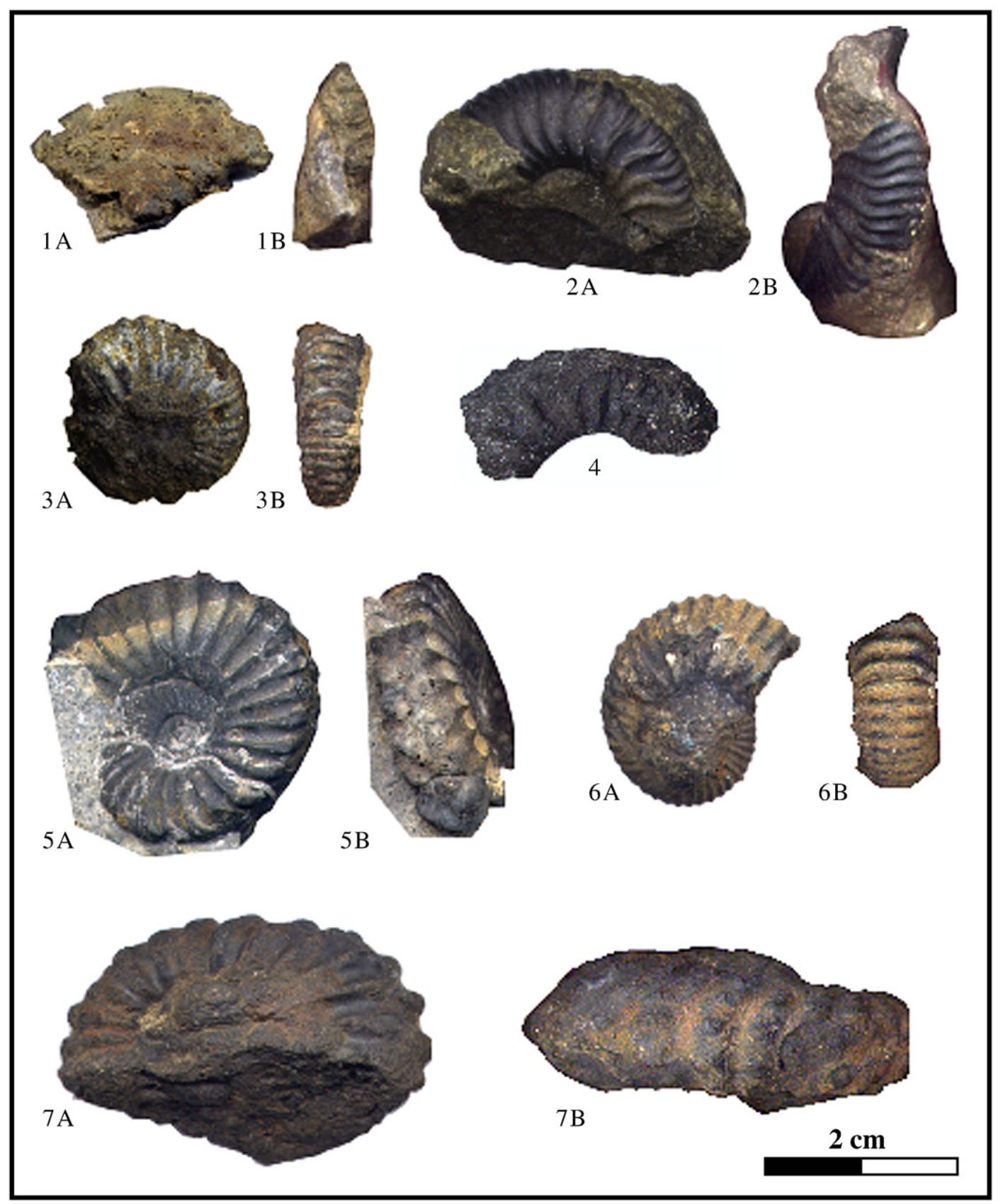

Fig. 7. Ammonites from the Garschella Formation near and at Col de la Plaine Morte: 1. Aconoceras nisus (d'Orbigny), identified by M. Delamette (Chartreuse National Park), Plaine Morte Bed; 2. Deshayesites sp., identified by J.-P. Thieuloy (University of Grenoble), Plaine Morte Bed; 3. Colombiceras sp., Luitere Bed; 4. Cheloniceras sp., Luitere Bed; 5. Leymeriella (Neoleymeriella) cf. intermedia Spath, Plattenwald Bed; 6. Hypacanthoplites sp., Plattenwald Bed; 7: Douvilleiceras sp., Plattenwald Bed.

Aptian values obtained on sections outside the Alps (e.g., Menegatti et al., 1998; Kuhnt et al., 1998) and as the general trend makes sense, these data are later on used for the interpretation of the age of this member.

\subsubsection{Luitere Bed (Early Late Aptian)}

The sediments of the Grünten Member or directly the sediments of the upper Schrattenkalk Member (in case the Grünten Member is absent) are overlain by a $5-20 \mathrm{~cm}$ thick, nodular phosphatic horizon the Luitere Bed, which is rich in coarse-grained quartz sand (Fig. 6E). Sediments of this bed may penetrate the underlying sediments of the Grünten Member in burrow-like fissure infills. This bed is particularly well-exposed in the outcrops NNE of the Col de la Plaine Morte, whereas further north ("Graui Felse") and on the Col de la Plaine
Morte itself (CH-Coord.: 600.820/135.620), its occurrence is restricted to fissure infills within the uppermost Schrattenkalk, right at the contact to the overlying Brisi Beds. The Luitere Bed contains Colombiceras sp. and Cheloniceras sp., which are both indicative of the subnodosocostatum and melchioris zones (Early Late Aptian; Fig. 7).

\subsubsection{Brisi Beds (Middle Late Aptian)}

The sediments of the Luitere Bed or directly the upper Schrattenkalk (in the case the Grünten Member is absent and the Luitere Bed is limited to fissure infills at the top of the Schrattenkalk Formation) are overlain by an up to $6 \mathrm{~m}$ thick, coarse-grained glauconite and phosphate-bearing sandstone, which grades into an alternation of coarse-grained quartz sands and calcarenite towards the top (i.e., Brisi Sandstone and Brisi Limestone; max. thickness 6 m; Fig. 3). The Brisi 


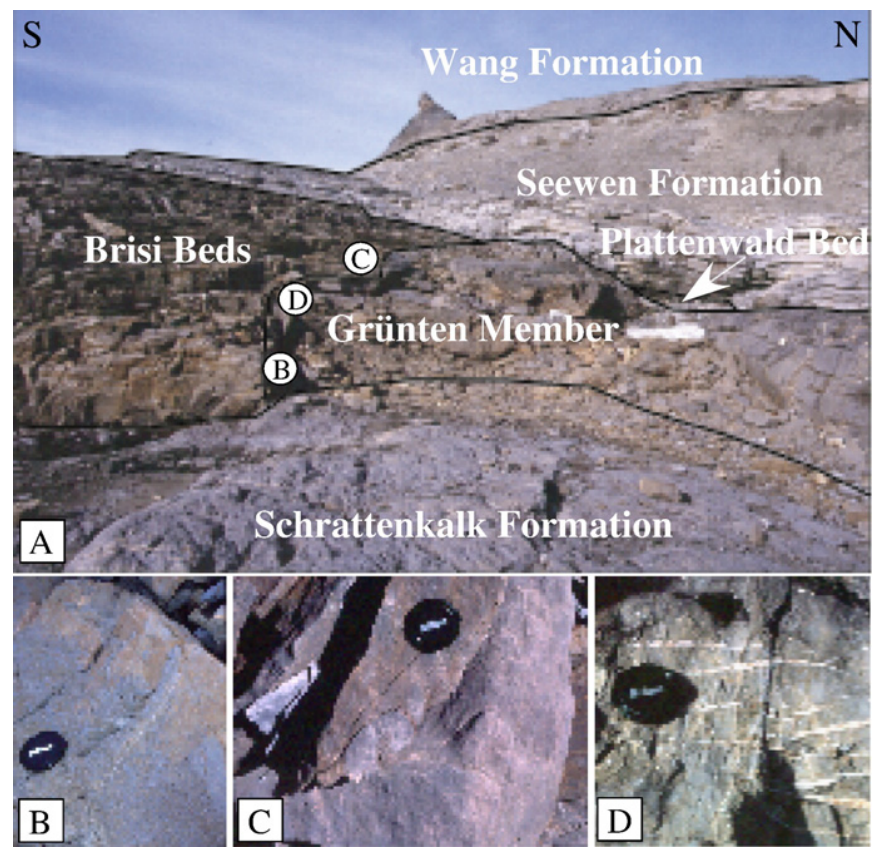

Fig. 8. An interesting juxtaposition of sediments of the Grünten Member and Brisi Beds is observed west of the $\mathrm{Col}$ de la Plaine Morte, where a succession of Schrattenkalk Formation-Grünten Member-Plattenwald Bed-Seewen Formation is laterally replaced to the south by a succession of Schrattenkalk Formation-Brisi Beds-Plattenwald BedSeewen Formation. The lateral contact between the sediments of the Grünten Member and the Brisi Beds is interpreted as synsedimentary, related to local erosion and removal of the sediments of the Grünten Member during deposition of the sediments belonging to the younger Brisi Beds. A. Overview; B. Local horizontal infiltrations of coarse-grained sands of the Brisi Beds into the fine-grained marly carbonates of the Grünten Member by bioturbation; C. Phacoid consisting of sediments of the Grünten Member at the base of the Brisi Beds; D. Infiltration of sediments of the Brisi Beds into the Grünten Member The exact location of B, C, and D is indicated in A, and the exact location of $A$ is indicated in Figs. 1 and 5.

Beds show distinct cross-stratifications with predominant southwards current directions (Fig. 6F). They are rich in small fish teeth.

An interesting juxtaposition of the Brisi beds and the Grünten Member is observed directly on the Col de la Plaine Morte itself, on its western flank, where a succession of upper Schrattenkalk-Grünten Member-Plattenwald Bed-Seewen Formation is replaced to the south by a succession of upper Schrattenkalk-Brisi Beds-Plattenwald BedSeewen Formation (Figs. 5 and 8). The lateral contact between the sediments of the Grünten Member and the Brisi Beds is very sharp, and descends in a rather steep and step-wise manner. It is locally marked by Thalassinoides and by the presence of up to $10 \mathrm{~cm}$ large cobles and phacoids of sediments from the Grünten Member at the base of the Brisi Beds (Fig. 8).

\subsubsection{Plattenwald Bed (latest Aptian-Middle Turonian)}

The Plattenwald Bed covers the sediments of the Brisi Beds and locally directly the sediments of the Grünten Member. It consists of a maximally $40 \mathrm{~cm}$ thick nodular phosphatic bed, which shows a variety of matrices consisting of glauconitic sandstone, glauconitic sandy micritic limestone, and micritic limestone (from the base to the top). In the outcrop NNE of the Col de la Plaine Morte, an isolated glauconitic sandstone lens with a length of approximately $70 \mathrm{~cm}$ and a maximal thickness of $4 \mathrm{~cm}$ showing internal cross-laminations appears in the middle part of the Plattenwald Bed (Fig. 6G). A quarzite pebble with a maximum diameter of $3.4 \mathrm{~cm}$ was found within the Plattenwald Bed at the Col de la Plaine Morte (Fig. 6H).

The Plattenwald Bed contains abundant phosphatized fossil remains, including ammonites, brachiopods, inoceramid bivalves, belemnites, and gastropods. A single fragment of Chaetetopsis sp. was observed (Reitner and Föllmi, 1991). The outcrops at the Col de la Plaine Morte show stromatolitic structures within the micritic limestone at the top of the Plattenwald Bed (Fig. 9). An inspection of a selection of stromatolite samples by electronic scanning microscope reveals the presence of filamentous microbial-like structures, which are excellently preserved (Fig. 9).

The Plattenwald Bed at and south of the Col de la Plaine Morte yielded an interesting ammonite fauna, which in terms of biostratigraphic markers is restricted to Hypacanthoplites, Leymeriella and Douvilleiceras (Fig. 7). Schaub (1936) also identified Hoplites of the dentatus group and Lyelliceras; in the collection of M. Lugeon, a single specimen of Mariella bergeri was identified from this region (Schaub, 1936). This association indicates a latest Aptian to Early Middle Albian age (jacobi, tardefurcata, mammillatum and dentatus zones) for the main phase of phosphogenesis, if we discard the single Mariella specimen. According to Schaub (1936), occurrences of the Plattenwald Bed further to the north contain predominantly ammonites of Late Albian age (Schaub, 1936).

Associations of planktonic foraminifera of different age are associated with different types of micritic matrix: 1) a micrite rich in quartz and glauconite contains Rotalipora ticinensis (Gandolfi), R. cushmani (Morrow), and Praeglobotruncana stephani (Gandolfi) (Late Albian to Late Cenomanian; this type of matrix is restricted to occurrences north of the Col de la Plaine Morte); 2) a micrite with few glauconite and quartz grains includes Dicarinella hagni (Scheibnerova), D. algeriana (Caron), Praeglobotruncana gibba Klaus, Whiteinella archeocretacea Pessagno, W. inornata (Bolli), Helvetoglobotruncana praehelvetica (Trujillo), H. helvetica (Bolli) (Late Cenomanian to Middle Turonian) (Fig. 10).
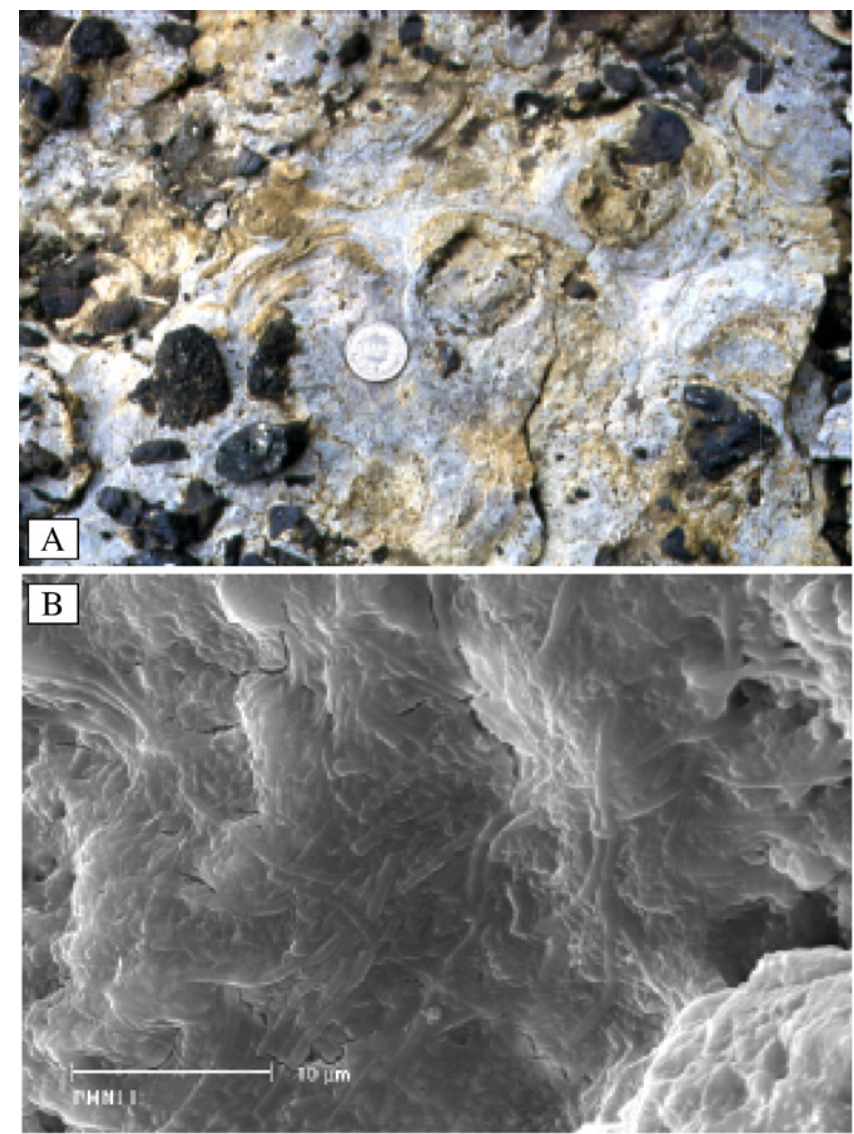

Fig. 9. Stromatolitic structures preserved in micritic carbonate at the top of the Plattenwald Bed at the Col de la Plaine Morte: . Outcrop photo (coin diameter $=2.3 \mathrm{~cm}$ ); B. SEM micrograph showing filamentous microbial-like structures. The exact location is indicated in Fig. 1. 

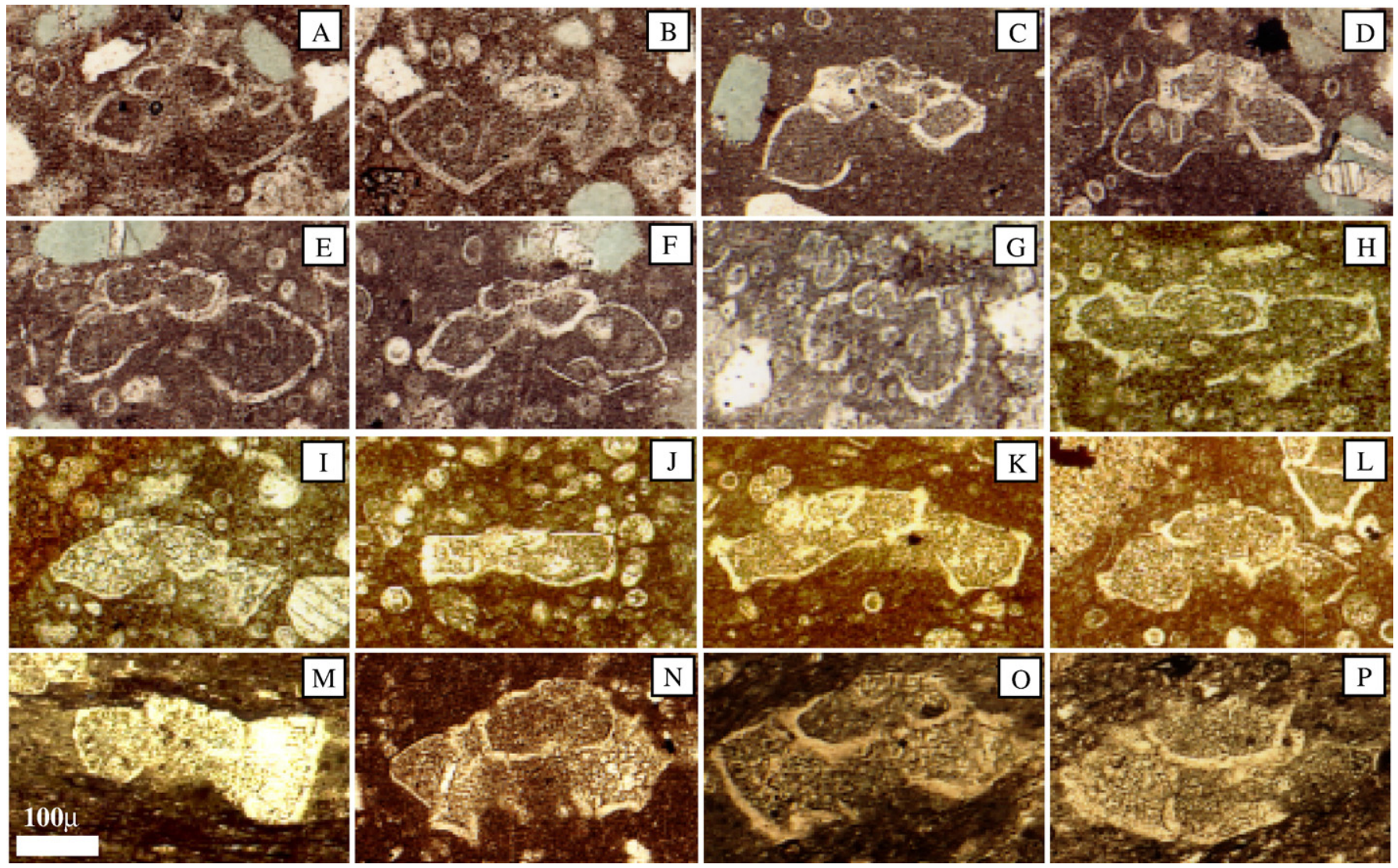

Fig. 10. Selection of Globotruncanidae identified by Michèle Caron (University of Fribourg) within the Plattenwald Bed and overlying Seewen Formation: A. Rotalipora ticinensis (Gandolfi) (Plattenwald Bed); B. Rotalipora cushmani (Morrow) (Plattenwald Bed); C. Dicarinella hagni (Scheibnerova) (Plattenwald Bed); D. Dicarinella algeriana (Caron) (Plattenwald Bed); E. Whiteinella archeocretacea Pessagno (Plattenwald Bed); F. Whiteinella inornata (Bolli) (Plattenwald Bed); G. Helvetoglobotruncana helvetica (Bolli) (Plattenwald Bed); H. Marginotruncana coronata (Bolli) (base Seewen Formation); I. Marginotruncana schneegansi (Sigal) (base Seewen Formation); J. Falsotruncana maslakovae Caron (base Seewen Formation); K. Marginotruncana pseudolinneiana Pessagno (base Seewen Formation); L. Marginotruncana sigali (Reichel) (base Seewen Formation); M. Dicarinella concavata (Brotzen) (lower marly interval within Seewen Formation); N. Rosita fornicata (Plummer) (upper calcareous interval within Seewen Formation); O. Globotruncanita stuartiformis (Dalbiez) (upper marly interval within Seewen Formation); P. Globotruncana arca Cushman (upper marly interval within Seewen Formation).

\subsection{Seewen Formation (Late Turonian-Campanian)}

The Plattenwald Bed is directly overlain by pelagic, micritic carbonates of the Seewen Formation, which are very rich in calcispheres, inoceramid prisms and planktonic foraminifera, and which reach a thickness of approximately $40 \mathrm{~m}$ at the Col de la Plaine Morte. The micritic matrix of the upper part of the underlying Plattenwald Bed is comparable to the sediments of the Seewen Formation with regards to its facies (Föllmi, 1986). The Seewen Formation itself consists from base to top of $5 \mathrm{~m}$ pelagic, micritic limestone, $15 \mathrm{~m}$ sand-containing marlstone, $3 \mathrm{~m}$ pelagic micritic limestone, and $10 \mathrm{~m}$ sandy marlstone.

The limestone at the base of the Seewen Formation is composed of a pure micrite rich in calcispheres, inoceramid prisms, and Saccocoma, in which D. hagni, Marginotruncana pseudolinneiana Pessagno, $M$. coronata (Bolli), M. schneegansi (Sigal), M. sigali (Reichel), and Falsotruncana maslakovae Caron were identified (Late Turonian). The lower marly interval includes Dicarinella concavata (Brotzen), D. aff. asymetrica (Sigal), and M. pseudolinneiana Pessagno (Santonian). The upper calcareous part contains Globotruncanita sp., Rosita fornicata Plummer, and M. pseudolinneiana Pessagno (Late Santonian), whereas the upper marly interval hosts Globotruncana arca Cushman, Globotruncanita stuartiformis (Dalbiez), and Archeoglobigerina cretacea (d'Orbigny) (Late Santonian to Late Campanian) (Fig. 10).

\subsection{Normal faults in association with the Seewen Formation}

Breccia deposits are located north of the Col de la Plaine Morte (CH-Coord.: 600.780/135.830; Figs. 1 and 11). The breccia components consist of sediments from the Schrattenkalk Formation, the Garschella Formation, and the Seewen Formation, which are embedded in a matrix of pelagic micrite of the Seewen Formation. The breccia deposits are associated with two subvertical normal faults, which separate the Urgonian Formation from the Seewen Formation (Fig. 11). The first fault is approximately $\mathrm{N}-\mathrm{S}$ oriented and the second approximately E-W (Figs. 1 and 5).

A sample of the Seewen Formation directly in contact with the breccia deposits include Dicarinella asymetrica (Sigal), D. concavata (Brotzen), M. pseudolinneiana Pessagno, and M. marginata (Reuss), indicating an age not younger than the Santonian for the generation of the normal faults and formation of the associated breccia deposits.

\subsection{Wang Formation (Maastrichtian), Klimsenhorn and Wildstrubel} Formations (Middle Eocene) and "Globigerina Marl" (Late Eocene)

On the Col de la Plaine Morte, the sediments of the Seewen Formation are directly overlain by approximately $20 \mathrm{~m}$ well-bedded, sandy and marly limestone, which belong to the Wang Formation. This formation shows an angular discontinuity at its base, and to the west and south of the Col de la Plaine Morte, it may directly follow on top of sediments of the Garschella and Schrattenkalk Formations, thereby gaining in thickness (up to $200 \mathrm{~m}$; Stacher, 1980). This formation is dated as Late Campanian to Late Maastrichtian (Stacher, 1980).

The sediments of the Wang Formation are overlain by approximately $7 \mathrm{~m}$ of glauconitic and quartz sandstone, and sandy limestone rich in Discocyclina and Nummulites, which are followed by approximately $20 \mathrm{~m}$ of sandy shales (Klimsenhorn and Wildstrubel Formations; Middle 
S
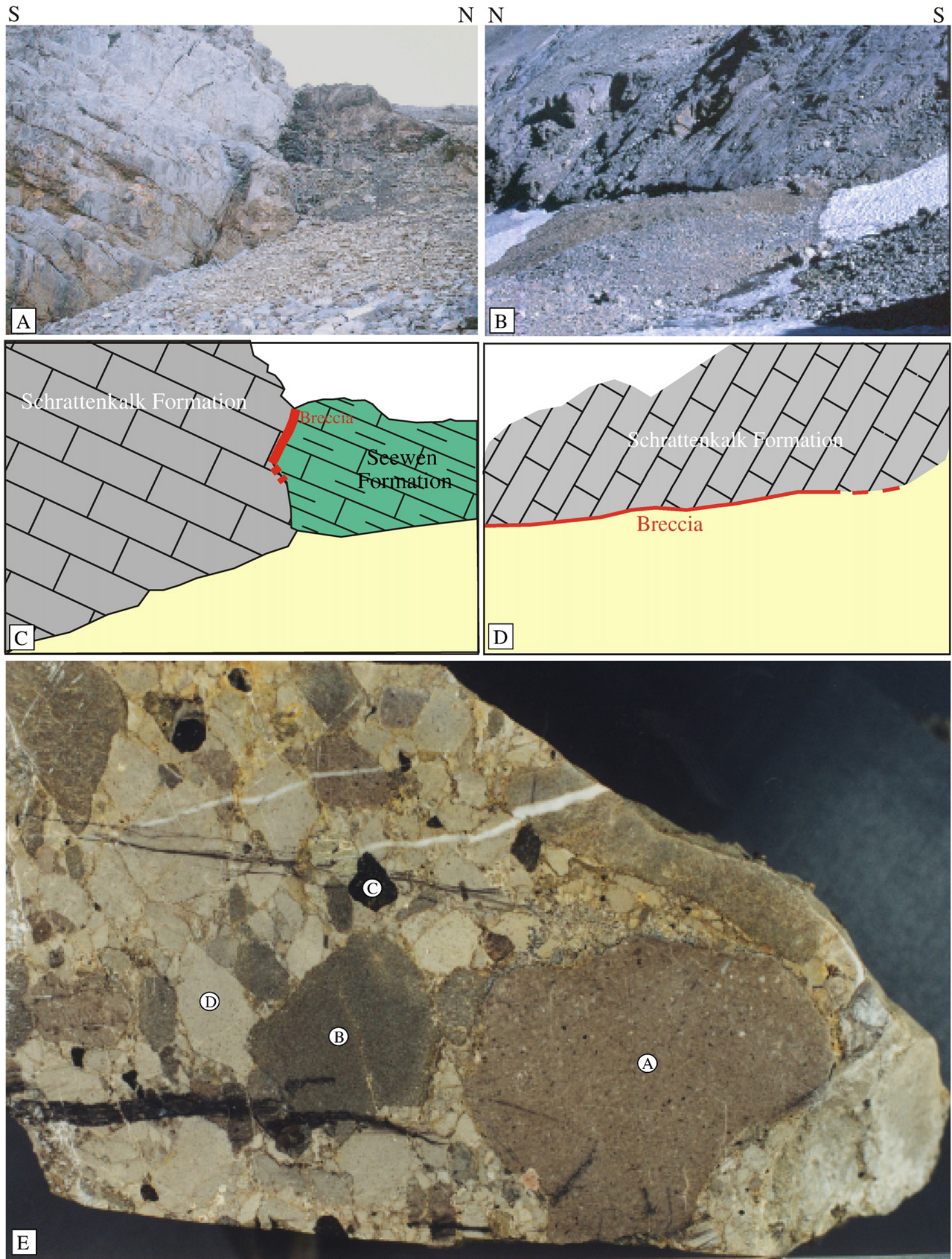

E
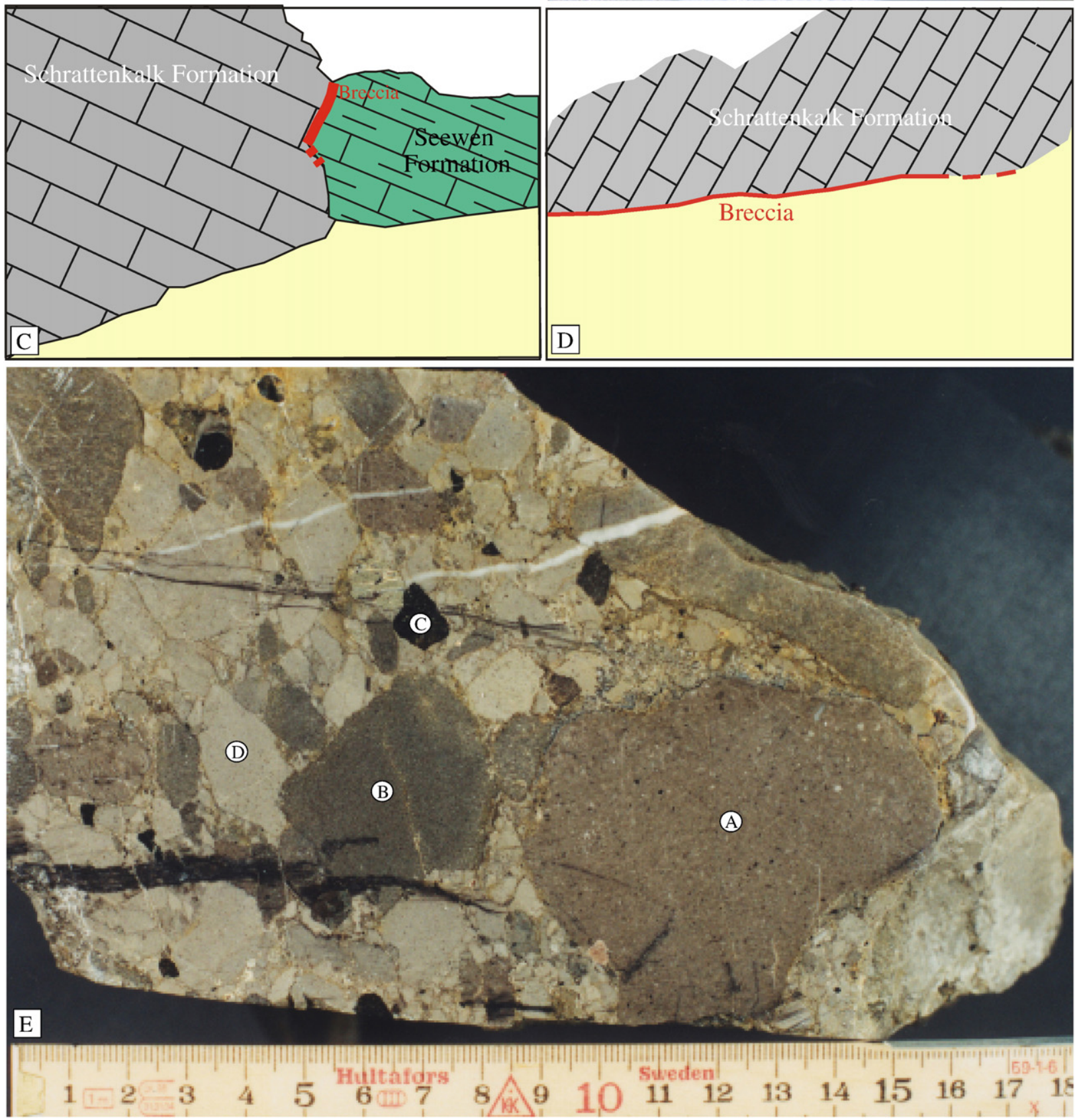

Fig. 11. Synsedimentary normal faults juxtaposing sediments of the Schrattenkalk Formation and Seewen Formation north of the Col de la Plaine Morte; A. and C. Sediments of Schrattenkalk Formation in lateral contact with sediments of the Seewen Formation. A breccia plasters the contact zone; B. and D. Sediments of the Schrattenkalk Formation are cut off by a synsedimentary fault associated with breccia. E. Polished slab of breccia showing components of the Schrattenkalk Formation (A), Grünten Member (B) and Seewen Formation (D), and phosphatic nodules and particles of the Garschella Formation. The exact locations are indicated in Figs. 1 and 5. 
Eocene; Menkfeld-Gfeller, 1995, 1997), and maximally 200 m of marl ("Globigerina Marl”: Late Eocene).

\section{Discussion}

5.1. Timing of the drowning phases of the Urgonian carbonate platform in the Col de la Plaine Morte area

The Aptian sediments of the Col de la Plaine Morte area represent one of the most differentiated successions of the entire Helvetic realm (Linder et al., 2006). Usually, in more proximal areas, the Grünten Member is missing and the Urgonian Schrattenkalk Formation is directly overlain by sediments of the Luitere Bed or younger sediments of the Garschella Formation (Föllmi, 1986, 1989; Föllmi and Ouwehand, 1987; Ouwehand, 1987; Delamette, 1988; Delamette et al., 1997). In distal sections, where sediments of the Grünten Member are present, they normally do not include phosphatic horizons, which are as well-developed and individualized as in the Col de la Plaine Morte area (Linder et al., 2006).

The age of the Grünten Member at this particular site is constrained both by the findings of Deshayesites and A. nisus (d'Orbigny) within the Plaine Morte Bed, which is therefore attributed to the deshayesi and furcata zones, as well as by the evolution of the $\delta^{13} \mathrm{C}$ record, which - if our correlation with the general $\delta^{13} \mathrm{C}$ record of SE France is correct - indicates that the time equivalent of almost the entire deshayesi zone and most of the furcata zone is represented by this member (Fig. 12).

The first episode of erosion and phosphogenesis, recorded in the Rohrbachstein interval directly on top of the Urgonian Schrattenkalk Formation, can therefore not be younger than the base of the deshayesi zone. We correlate this phase with the onset of the "upper Orbitolina Beds" in the Vercors area, where it has been dated as latest weissi zone, near the boundary between the weissi and deshayesi zones (SbA2; Arnaud et al., 1998) (Fig. 13).

The second phase of phosphogenesis, preserved within the Grünten Member, was associated with a halt in sedimentation and the formation of a nodular phosphatized surface (Plaine Morte Bed). According to the $\delta^{13} \mathrm{C}$ record and the presence of ammonites, the Plaine Morte Bed is dated as equivalent to the late part of the deshayesi zone and the early part of the furcata zone, and may - for its onset correspond in age to oceanic anoxic episode 1a (OAE 1a; Goguel or Selli level), which is also correlated with a positive shift in the $\delta^{13} \mathrm{C}$ record (Menegatti et al., 1998) (Fig. 13). Unlike Weissert and Erba (2004) and Gradstein et al. (2004), who dated the positive shift in the $\delta^{13} \mathrm{C}$ record and OAE 1 a as equivalent to the weissi zone, we place $\mathrm{OAE}$ $1 \mathrm{a}$ within the deshayesi zone, thereby using the ammonite-calibrated evolution of the $\delta^{13} \mathrm{C}$ record in the area of Cassis-La Bédoule (Kuhnt et al., 1998; cf. also Föllmi et al., 2006) and the age of the "niveau Goguel", which is dated as deshayesi zone (e.g., Bréhéret, 1997).

These ages allow us to develop a scheme of stepwise drowning of the Urgonian platform, which started with a first halt in platform buildup, accompanied by erosion and phosphogenesis just before the limit between the weissi and deshayesi zones (Fig. 13). This drowning phase terminated platform buildup in a predominantly photozoan mode accompanied by patch-reef growth so typical for the upper part of the upper Schrattenkalk. This first drowning phase was followed by carbonate production in a heterozoan mode, which started during the early deshayesi zone (lower Grünten Member). During the late deshayesi zone and early furcata zone, a second phase of phosphogenesis occurred, which was accompanied by erosion and hardground formation. Both the phase of carbonate production in a heterozoan mode and part of the following drowning phase are identical in time with OAE 1a (Figs. 12 and 13). During the later part of the furcata zone, carbonate production continued in a heterozoan mode (upper Grünten Member). The ammonites of the Luitere Bed indicate a further, protracted phase of halt in carbonate production, which is dated on the Col de la Plaine Morte as subnodosocostatum and melchioris zones, and which is generally inferred to have lasted from the late furcata zone to near the boundary between the melchioris and nolani zones (Föllmi et al., 2007). The Brisi Beds document a return to shallow-water carbonate production in a heterozoan mode, which occurred during the nolani zone. The base of the Plattenwald Bed, which is dated in the Col de la Plaine Morte area as Early to Early Middle Albian, is generally inferred to have already started during the jacobi zone. The Plattenwald Bed indicates the renewed return to phosphogenesis and condensation marks the final drowning phase of the northern Tethyan carbonate platform (Fig. 13).

The onset of platform drowning occurred prior to the widespread deposition of organic-rich sediments associated with OAE 1a and the accompanying positive excursion in pelagic $\delta^{13} \mathrm{C}$ records. The oceanic anoxic episode is materialized in the subsequent phase of heterozoan carbonate production and the second step of the drowning process, which is documented by condensation and phosphogenesis recorded in the Plaine Morte Bed. This offset in timing was already observed (Föllmi et al., 1994, 2007) and maybe related to the possibility that the Urgonian shallow-water carbonate platform reacted very sensibly to environmental change, whereas it took some additional time for the entire oceanic carbon cycle to adjust and correspondingly change its isotopic signature.

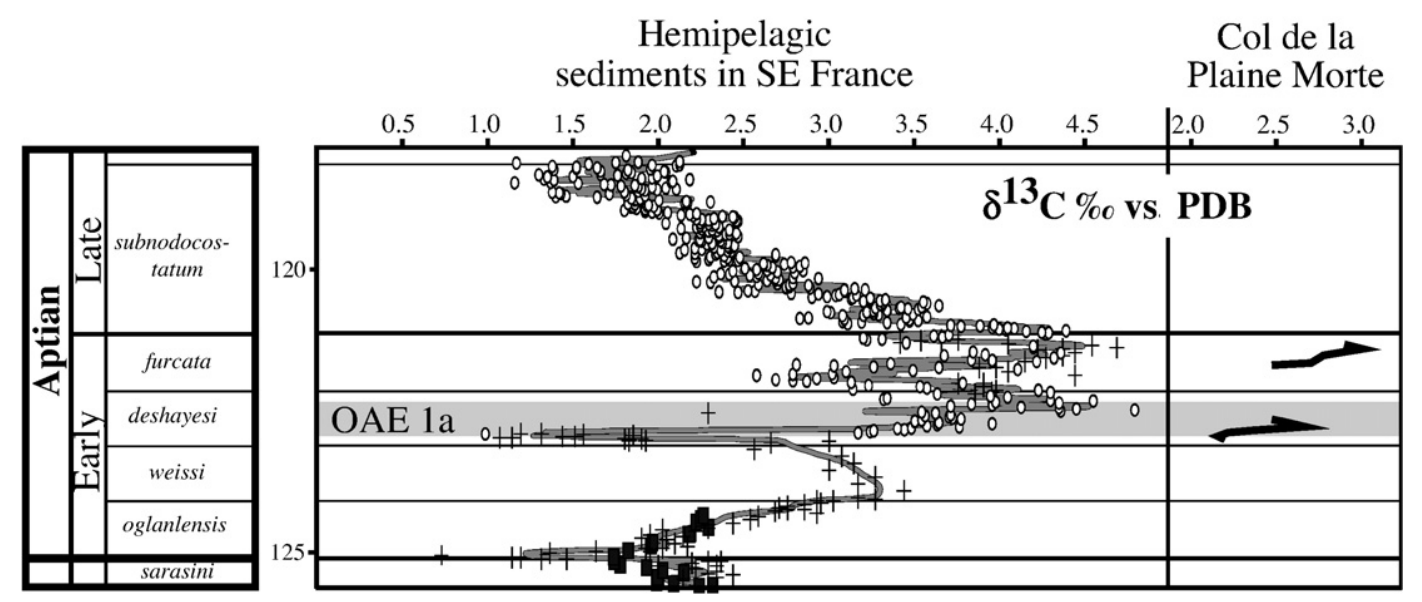

Fig. 12. Proposed correlation between the whole-rock $\delta^{13} \mathrm{C}$ record measured in the Grünten Member (Gainon, 2001) and the Early Aptian $\delta^{13} \mathrm{C}$ record from SE France (date shown by rectangles from Godet et al., 2006; by crosses from Moullade et al., 1998; by circles from Herrle et al., 2004; after Föllmi et al., 2006). 

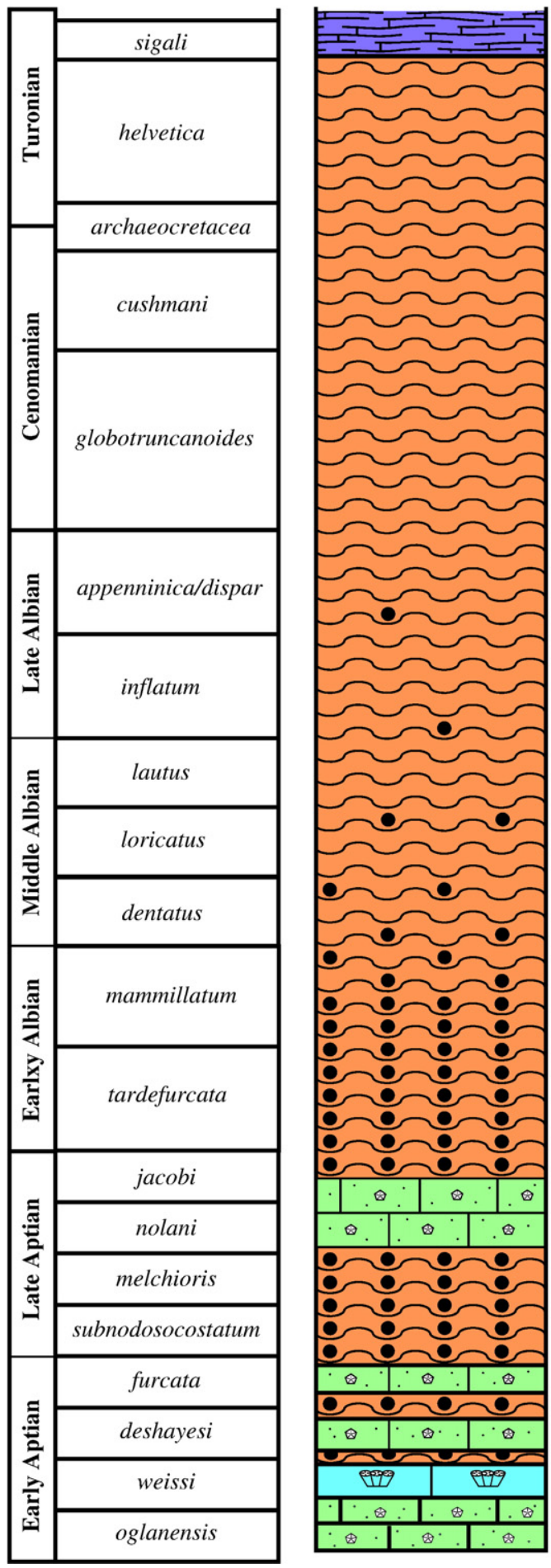
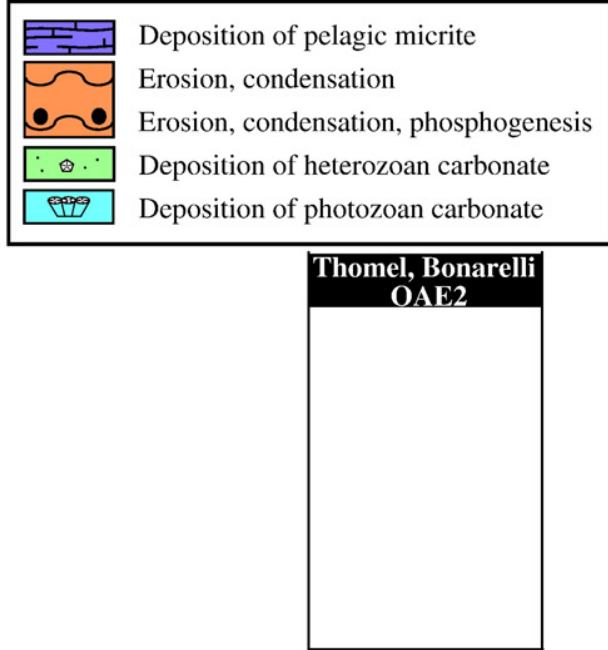

Breistrofier OAE 1d

Plattenwald Bed

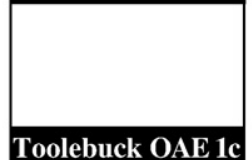

Ocean anoxic episodes

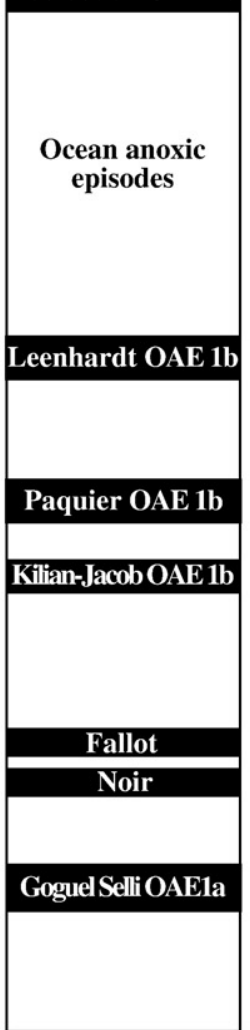

Brisi Beds

Luitere Bed

Upper Grünten

Plaine Morte Bed

Lower Grünten

Rohrbachstein Phase

Upper Schrattenkalk

Rawil Member

Fig. 13. Schematic time diagram showing the succession of sedimentary processes during the Aptian to the Turonian in the area of the Col de la Plaine Morte and their correlation to oceanic anoxic episodes.

\subsection{Erosion, condensation and phosphogenesis}

\subsubsection{The Rohrbachstein phase}

The stepwise-drowning phases of the Urgonian platform and the subsequent phase towards pelagic sedimentation are all marked by erosion, sediment reworking, and phosphogenesis. The Rohrbachstein phase is associated with differential erosion of the surface of the Urgonian Schrattenkalk Formation, leading to local incisions of up to several meters depth, which accommodated the main sedimentary volume of the subsequent Grünten Member (Fig. 14). The eroded surface of the Urgonian Schrattenkalk Formation underwent a subsequent phase of phosphogenesis, which affected selected parts of the surface, such as exposed coral remains (Linder, in prep.).

\subsubsection{The Plaine Morte phase}

The second phase of phosphogenesis documented in the Plaine Morte Bed is equally accompanied by erosion, which in this case led to the formation of a nodular surface, and peripherical phosphatization of the limestone nodules (Figs. 6C, 13, and 14). This horizon is associated with detrital quartz grains, glauconite, and sparse phosphate 


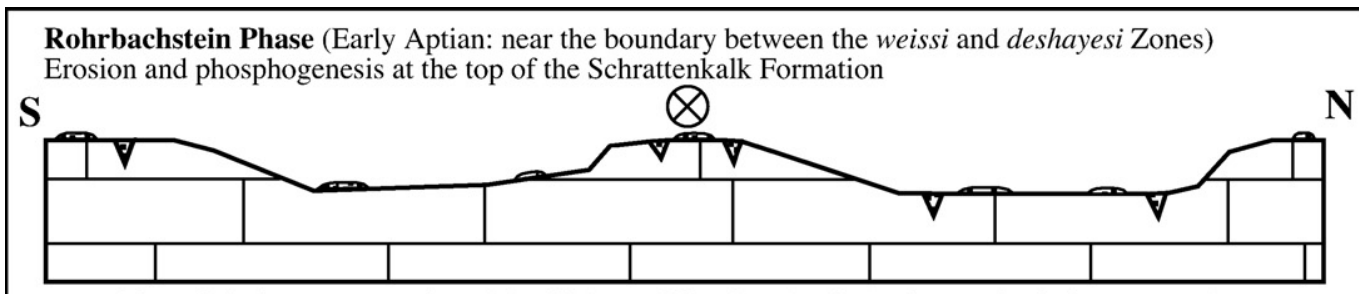

Deposition of the lower succession of the Grünten Member (Early Aptian: early deshayesi Zone)

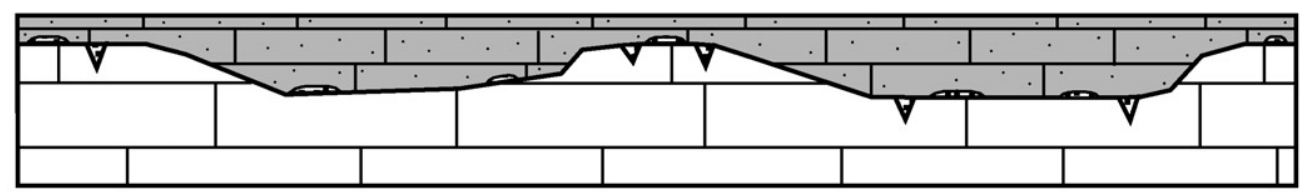

Plaine Morte Bed (Early Aptian: late deshayesi Zone to early furcata Zone)

Erosion, phosphogenesis

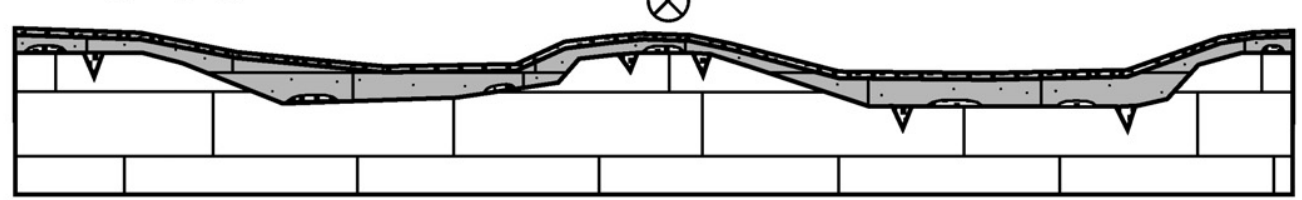

Deposition of the upper succession of the Grünten Member (Early Aptian: furcata Zone)

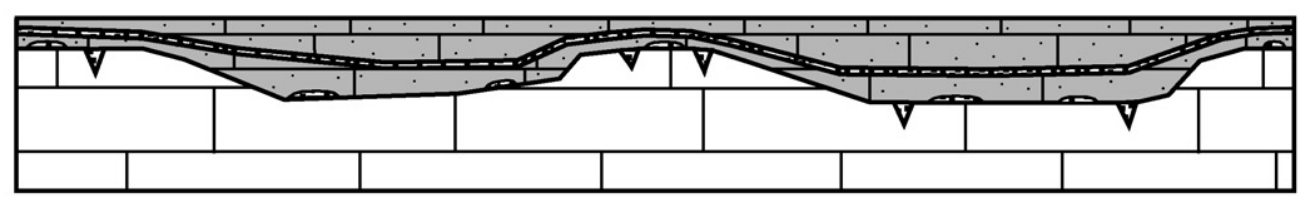

Luitere Bed (latest Early to Late Aptian: late furcata Zone to near the boundary melchioris-nolani Zones) Erosion, phosphogenesis, condensation

$\otimes$

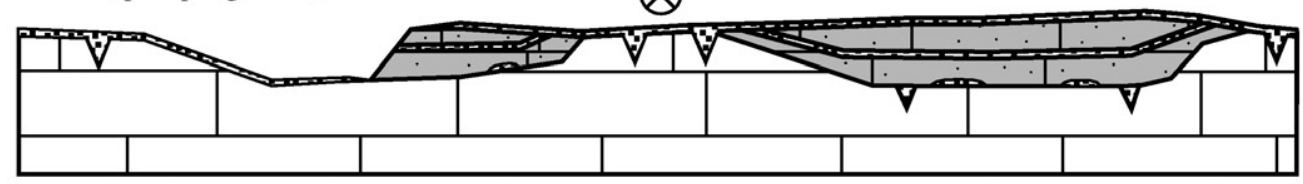

Deposition of the Brisi Beds (Late Aptian: nolani Zone)

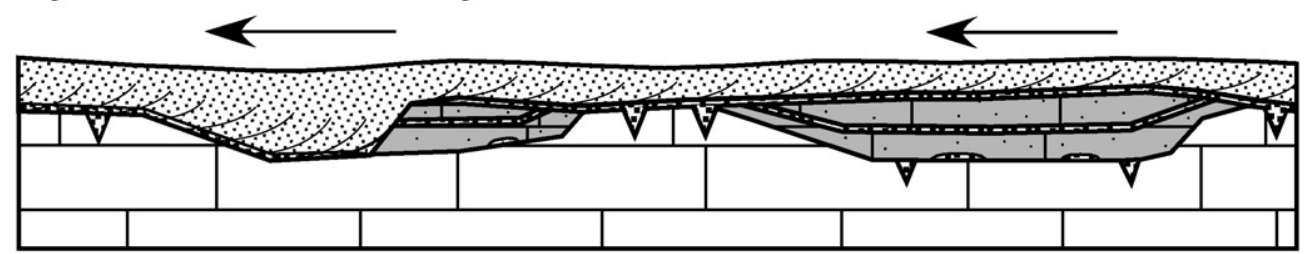

Plattenwald Bed (latest Aptian (jacobi Zone) to middle Turonian)

Erosion, phosphogenesis, condensation

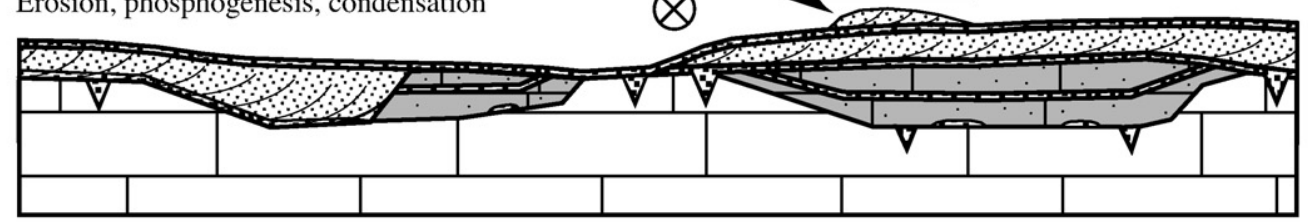

Deposition of the basal succession of the Seewen Formation (Late Turonian)

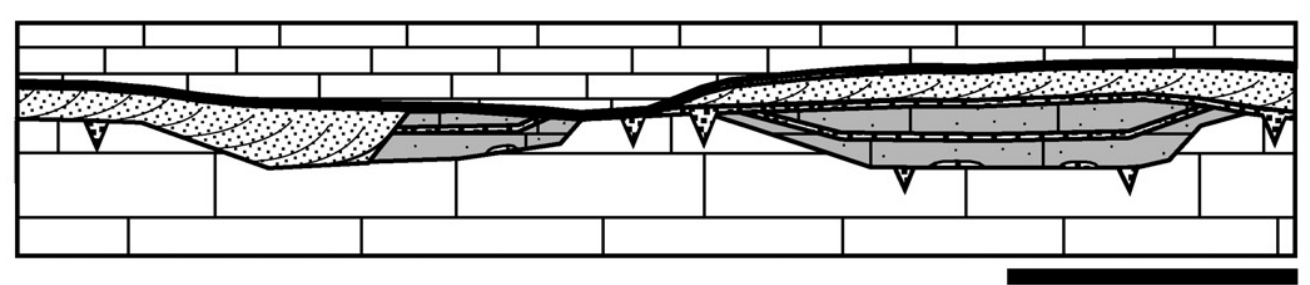

approx. $250 \mathrm{~m}$

Q-W directed main current 
nodules and particles - amongst them the above-mentioned phosphatized fragments of Deshayesites sp. and A. nisus (d'Orbigny). The presence of a mica-schist pebble of hercynian age indicates the rare inclusion of exotic material in this horizon (Fig. 6D). A further crystalline cobble was found in the Garschella Formation of Unter Klien, Vorarlberg, Austria, which was dated as Late Proterozoic (Föllmi, 1989). The origin of the pebble of the Plaine Morte Bed is probably similar to the one proposed for the Austrian cobble; i.e., a dropstone which was associated with floating wood (for example captured in the root network). Given its hercynian origin and the reconstructed eastwest oriented current system that followed the northern Tethyan margin, it may have originated from the western part of the Bohemian massif, which was exposed at that time (e.g., Föllmi and Delamette, 1991; Stampfli and Borel, 2002; Golonka, 2004).

The Plaine Morte phase of phosphogenesis is also known from distal occurrences of the Garschella Formation in Vorarlberg and Allgäu, where phosphates of this phase became integrated in phosphatic sediments of the younger Luitere Bed (Föllmi, 1986; Linder et al., 2006). In the Col de la Plaine Morte area, a local bundling of the Plaine Morte Bed with the overlying Luitere Bed is also observed (Figs. 6E, and 14).

\subsubsection{The Luitere phase}

The third phase of erosion and phosphogenesis is preserved in the sediments of the Luitere Bed. The base of the Luitere Bed is highly irregular and marked by the infill of fissures that may penetrate the underlying Grünten Member or upper Schrattenkalk for several 10's of $\mathrm{cm}$. The bed itself includes up to cobble-sized fragments of reworked sediments of the Grünten Member and Schrattenkalk Formation. The ammonites found in this area indicate an Early Late Aptian age, whereas more complete ammonite collections elsewhere in the Helvetic Zone indicate a time envelop spanning the latest Early Aptian to the Late Aptian (late furcata zone to near the boundary between the melchioris and nolani zones). The fact that this bed is very thin (max. $20 \mathrm{~cm}$ ) and in larger areas reduced to the fissure infills indicates the importance of erosion during and after its deposition. The biostratigraphic spread of ammonites in the Luitere Bed in general indicates a maximal time span of approximately 6 to 7 million years of condensation, according to Gradstein et al. (2004) (Fig. 14).

\subsubsection{The Plattenwald phase}

Schaub (1936) described the presence of different types of sediments in ammonites of different biostratigraphic ages occurring within the Plattenwald Bed of the region of the Col de la Plain Morte and north of it (Rawil, Wildstrubel, Schneidehorn). Using differences in grain-size distributions of quartz and glauconite, differences in the degree of roundness, and presence of foraminifera and bioclasts, he was able to distinguish eight different types of sediment infill in ammonites of different biostratigraphic zones in the latestmost Aptian and the entire Albian. Ammonites of the same biostratigraphic zone include the same type of sediment infill. He concluded that the formation of the Plattenwald bed witnessed at least eight phases of 1) sedimentation; 2) sediment infill of ammonites, phosphogenesis, and fossilization; 3) erosion, winnowing and transport; and 4) reworking of coarser grained particles (phosphatic nodules, fossils) into the following phase of sedimentation (see also Schaub, 1948). He also noted that whereas most ammonites in the region of the Col de la Plaine Morte indicate a latest Aptian to Early Middle Albian age, the ammonites within the same bed in regions north of the Col de la Plaine Morte indicate preferentially a Late Albian age.

The scenario of formation of the Plattenwald Bed in the region of the Col de la Plaine Morte proposed by Schaub (1936) is confirmed and complemented here. We assume that the zone of condensation was current-swept (Föllmi and Delamette, 1991) and episodically covered by relict sands, which were bypassed to the outer-shelf zone (Föllmi, 1986, 1989, 1990). A small cross-bedded sand lens within the
Plattenwald Bed (Figs. 6G and 14) is interpreted as such a body of relict sand that remained preserved in the area of condensation. The presence of cross-stratification within this lens indicates that the process of deposition was fast. The bypassing of sands may therefore have been episodic, in a stop-and-go manner, thereby burying benthic and benthos-related ecosystems, which were fossilized and phosphatized as such. After the removal of the relict sand, the phosphatized fossils and larger particles were concentrated by winnowing and eventually incorporated in a following wave of relict sand bypassing the zone of condensation.

Once the sand supply stopped, phosphogenesis stopped as well (during the Middle Albian; Fig. 13), and in the following the carpet of phosphatic fossils and particles trapped different generations of micritic sediments, which date from the Late Albian to Middle Turonian. The deliverance of micritic sediments occurred probably also under the influence of a current system impinging on the outer margin of the drowned platform, since the deposition of micritic sediments of this period are only known from the highly condensed Plattenwald Bed, whereas coeval and identical sediments were deposited within the Seewen Formation further to the north.

This signifies that the duration of phosphogenesis within the Plattenwald Bed of the Col de la Plaine Morte area was restricted from the latest Aptian to the Middle Albian, whereas further to the north, this process lasted until the Late Albian. The process of condensation itself, however, did not stop before the Middle Turonian. A comparable process of phosphogenesis and condensation of comparable duration has also been documented from distal occurrences of the Plattenwald Bed in Vorarlberg (Föllmi, 1986, 1989).

During the later, "micritic" stage in the phase of condensation, stromatolitic structures formed and were excellently preserved within the micrite filling in the pore space of the Plattenwald Bed (Fig. 9). These stromatolites are so-called deep-water stromatolites, which were installed on the outer margin of the drowned platform. In distal areas of the drowned Urgonian carbonate platform, stromatolites are well known from Cenomanian sediments and are documented from eastern France (Delamette, 1981, 1988), from eastern Switzerland (Churfirsten region; Ouwehand, 1987) and from Vorarlberg (Föllmi, 1986, 1989).

Similar to the mica-schist pebble in the Plaine Morte Bed, the exotic quarzite pebble in the Plattenwald Bed may be interpreted as a dropstone, probably transported in the root network of a rafted tree (Fig. 6H).

\subsubsection{Overall duration of condensation and phosphogenetic processes in the Col de la Plaine Morte area}

In the area of the Col de la Plaine Morte, the process of condensation and phosphogenesis started already in the Early Aptian, near the boundary between the weissi and deshayesi zones, and was only interrupted by three rather short periods of carbonate accumulation in a heterozoan mode (lower and upper part of the Grünten Member, Brisi Beds) during the Aptian. The process of condensation continued during the entire Albian and Cenomanian, and ended somewhere within the Middle Turonian. Processes of phosphogenesis stopped, however, already in the Middle Albian. The sporadic inclusion of younger phosphatized fossils may be related to the reworking and lateral transport of these fossils from a more proximal realm, where phosphogenetic processes lasted until the Late Albian. This signifies that - following the initial phase of platform drowning condensation was the predominant process reigning on what remained of the Urgonian platform during more than 30 million years (Gradstein et al., 2004). The drowned platform was current-swept during this period, and saw the episodic bypassing of relict detrital sediments towards more distal areas during the Aptian to Middle Albian. Afterwards, pelagic micritic sediments of Late Albian to Middle Turonian age became trapped in the remaining pore space within the carpet of palimpsest, partly phosphatized fossils, particles, and pebbles. 


\subsection{Pelagic sedimentation and the installation of normal faults}

This prolonged phase of condensation ceased somewhere between the Middle and Late Turonian, to give place to the regular deposition of pelagic, micritic carbonate (Seewen Formation). The deposition of carbonates comparable in facies and equally attributed to the Seewen Formation started earlier in more proximal parts on the Helvetic shelf, between the latest Albian and Middle Cenomanian. The zone of prolonged condensation is limited to the outer margin of the drowned Urgonian platform, which became more accentuated during the Early Late Cretaceous, probably through processes of differential subsidence. In the outer shelf beyond the platform margin, the change to a pelagic regime occurred also during the latest Albian (Föllmi, 1986, 1989; Ouwehand, 1987; Delamette, 1988).

Of interest here is the presence of two normal faults, which are arranged perpendicularly (Figs. 1 and 11). Normal faults associated with breccia, which exposed already lithified carbonates of the Urgonian platform are also known from the Vorarlberg area, and are associated with phases of important sediment reworking ("Götzis Beds"). These phases were probably triggered by differential compaction and subsidence, leading to a partial collapse of the outer platform margin. A tectonic influence is not excluded neither (Föllmi, 1981, 1986, 1989).

5.4. The disappearance of the Urgonian platform in the context of paleoenvironmental change

Initial drowning of the Urgonian carbonate platform during the Early Aptian has also been documented from other areas within the Helvetic Zone, such as in Allgäu (Linder et al., 2006) and Vorarlberg (Föllmi, 1986, 1989; Bollinger, 1988). A very comparable and wellcorrelated pattern of drowning is also known from the Vercors area (e.g., Arnaud-Vanneau et al., 1976; Arnaud et al., 1998), and from the Spanish Pyrenees (Bernaus et al., 2003). In the Monts de Vaucluse, S France, the Urgonian succession includes a rudist-bearing succession (U2 in Masse et al., 1999), which is replaced by a succession of bioclastic carbonates (U3 in Masse et al., 1999) near the limit between the weissi and deshayesi zones. The top of the bioclastic carbonate succession is dated as furcata zone (Masse et al., 1999; cf. also Masse, 1993).

In Oman, platform sediments equivalent to OAE 1a are characterized by the presence of a Lithocodium/Bacinella association, which is interpreted to have resulted from increased trophic levels (Pittet et al., 2002; Hillgärtner et al., 2003; Immenhauser et al., 2005). In N Mexico, the disappearance of the rudist-bearing shallow-water carbonates of the Cupido Formation is dated as Early Aptian (Bralower et al., 1999; Lehmann et al., 1999).

This compilation of platform drowning pattern during the Early Aptian across the Tethyan realm suggests that the causes are to be sought on at least a Tethyan-wide scale. The correlation between platform drowning and evolving OAE's has been evoked by many authors (e.g., Schlager and Philip, 1990), and the links between the drowning steps identified in the Col de la Plaine Morte area and OAE's probably confirm a causal relationship, even if the onset of the drowning phases slightly predates the OAE's. An often-suggested mechanism invokes increases in trophic levels, which were related to the increased availability of nutrients such as phosphate. There are several indications, which are in favor of this scenario: 1) the overall change from photozoan-dominated to heterozoan-dominated and Lithocodium/Bacinella-containing carbonates near the boundary between the weissi and deshayesi zones; 2) the importance of phosphogenesis during the drowning phases along the northern Tethyan margin; and 3) a general increase in phosphorus-burial rates during the Early Aptian, which correlates rather well with the whole-rock $\delta^{13} \mathrm{C}$ record (Föllmi et al., 2007).

Changes in trophic levels are generally viewed as the result of climate warming and an increase in biogeochemical weathering rates on the continents, and indications for this are given in the Col de la Plaine Morte area by a corresponding stepwise increase in detrital quartz input, starting with the sediments of the Grünten Member. These changes were accompanied by general sea-level rise, which started in the weissi zone and culminated during OAE 1a in the deshayesi zone (Haq et al., 1987). The ultimate mechanism for environmental change may be linked with increased tectonic and volcanic activity, and evidence for this is given by the formation of the Ontong-Java large igneous province and eventually also by a compilation of oceanic crust production rates, in which an acceleration is suggested for the Early Aptian (Larson, 1991; Courtillot and Renne, 2003; Taylor, 2006).

Independent of all inferences and interpretations, it is more and more evident that a phase of major change occurred during the Middle Early Aptian - near the limit between the weissi and deshayesi zone, which terminated reef growth on a wider scale and lead to the widespread disappearance of Urgonian-type, photozoan carbonate platforms. This phase preceded OAE 1a, which occurred during the deshayesi zone, and which overlaps with a second phase of platform deterioration. A further phase of protracted platform drowning phase started in the late furcata zone and lasted during most of the Late Aptian. A final drowning phase occurred near the Aptian-Albian boundary, which gave a "coupe de grace" to those portions of the northern Tethyan carbonate platform system, which are presently locked up in the Helvetic Alps.

\section{Conclusions}

The sediments of the Helvetic thrust- and fold belt exposed in the Col de la Plaine Morte area (central Switzerland) are of special interest, since they provide one of the most complete and differentiated records of the succession of drowning phases which led to the demise of the Urgonian carbonate platform. They also document the subsequent phase of prolonged condensation, followed by pelagic sedimentation on top of the drowned Urgonian platform.

A first drowning phase associated with important erosion and local phosphogenesis, which terminated photozoan carbonate production on top of the Urgonian platform, is dated as just before the boundary between the weissi and deshayesi zones (Middle Early Aptian). This phase is followed by a phase of carbonate production in a heterozoan mode, and, consequently, by a second drowning phase associated with erosion, condensation, and phosphogenesis, which is dated as the late deshayesi to early furcata zones (Late Early Aptian). A second phase of carbonate production in a heterozoan mode is documented somewhere in the middle part of the furcata zone, and a third drowning phase associated with erosion, condensation and phosphogenesis started in the late furcata zone, and lasted until near the boundary between the nolani and melchioris zones (Middle Late Aptian). A third and final phase of carbonate production in a heterozoan mode is documented from the melchioris zone, which was followed by a fourth and final drowning phase, which is again associated with erosion, condensation and phosphogenesis, and which started somewhere in the jacobi zone (latest Aptian).

This last phase of condensation lasted until the Middle Turonian, and documents a drowned outer platform margin, which was swept by an impinging current, and which was intermittently covered by bypassing relict sands. Phosphogenesis in this particular part of the platform lasted until the Middle Albian.

From the Middle Turonian onwards, the condensed sediments of the drowned platform margin were progressively covered by pelagic, micritic sediments. During this phase of pelagic carbonate deposition, the outer platform margin became subjected to normal faulting, which partly re-exposed the already lithified carbonates of the Urgonian platform at the seafloor. This phase of platform-margin structuration is interpreted as a partial collapse related to differential subsidence eventually in concert with a phase of increased tectonic activity. 
Judging the ages obtained by ammonite biostratigraphy and $\delta^{13} \mathrm{C}$ whole-rock stratigraphy, the first platform drowning phase just preceded OAE $1 \mathrm{a}$, and the second drowning phase partly overlapped with OAE 1a. The onset of the third drowning event predated two further periods of increased organic-matter accumulation in the Vocontian Basin (Noir and Fallot levels), and the beginning of the fourth and final drowning phase coincided with two further periods of increased organic-matter accumulation in the Vocontian Basin (Jacob and Kilian levels, part of OAE 1b). These correlations suggest the presence of a relationship between the oceanic anoxic episodes and the stepwise demise of the Urgonian platform. Thereby, the platform appeared to have registered environmental change in a more rapid and sensible way than the sediments in the adjacent basin.

\section{Acknowledgements}

We thank Kristina Schenk (formerly at the University of Berne), Pascal Linder (University of Neuchâtel), Stéphane Bodin (University of Manchester), Alexis Godet (Neftex, Oxford), Pascal Kindler (University of Geneva), and Hanspeter Funk (Baden) for their help in the field, Michel Delamette (Natural Park, Chartreuse) and Jean-Pierre Thieuloy (University of Grenoble) for their help in the identification of the ammonites from the Plaine Morte Bed, Michèle Caron (University of Fribourg) for her help in the identification of the planktonic foraminifera, and the paleontological institute of the University of Zürich for the preparation of the Deshayesites specimen. We acknowledge Heidi Haas (University of Berne) for her help with the analysis of the stable carbon isotopes, Michael Cosca (University of Lausanne) for the ${ }^{40} \mathrm{Ar} /{ }^{39} \mathrm{Ar}$ age date on the mica-schist pebble of the Plaine Morte Bed, Michèle Vlimant and Massoud Dadras (University of Neuchâtel) for their help with the SEM and ESEM, André Villard (University of Neuchâtel) for the preparation of thin sections, Thierry Adatte (University of Neuchâtel) for his help in the interpretation of XRD analyses, and the Federal Department of Defense for the use of the cable car between Iffigen Alp and Rawil. We thank Peir Pufahl (Acadia University, Canada) and Jean-Noël Proust (University of Rennes) for their thoughtful and constructive reviews and Paul Pearson for his assistance during the review process.

\section{References}

Ager, D.V., 1981. The Nature of the Stratigraphical Record. John Wiley and Sons, New York. 122 pp.

Arnaud, H., Arnaud-Vanneau, A., Blanc-Alétru, M.-C., Adatte, T., Argot, M., Delanoy, G Thieuloy, J.-P., Vermeulen, J., Virgone, A., Virlouvet, B., Wermeille, S., 1998 Répartition stratigraphique des orbitolinidés de la plate-forme urgonienne subalpine et jurassiene (SE de la France). Géologie Alpine 74, 3-89.

Arnaud-Vanneau, A., Arnaud, H., Thieuloy, J.P., 1976. Bases nouvelles pour la stratigraphie des calcaires urgoniens du Vercors. Newsletter on Stratigraphy 5, 143-159.

Arthur, M.A., Schlanger, S.O., 1979. Cretaceous “Oceanic Anoxic Events" as causal factors in development of reef-reservoired giant oil fields. American Association of Petroleum Geologists Bulletin 63, 870-885.

Bernaus, J.M., Arnaud-Vanneau, A., Caus, E., 2003. Carbonate platform sequence stratigraphy in a rapidly subsiding area: the Barremian-Early Aptian of the Organyà basin, Spanish Pyrenees. Sedimentary Geology 159, 177-201.

Bodin, S., Godet, A., Vemeulen, J., Föllmi, K.B., 2006a. New data on the age of the installation of Urgonian-type carbonates along the northern Tethyan margin: biostratigraphy of the Chopf Member (Helvetic Alps, eastern Switzerland). Comptes Rendus Geoscience 338, 727-733.

Bodin, S., Godet, A., Vermeulen, J., Linder, P., Föllmi, K.B., 2006b. Biostratigraphy, sedimentology and sequence stratigraphy of the latest Hauterivian-Early Barremian drowning phase of the northern Tethyan margin (Altmann Beds, Helvetic nappes, Switzerland). Eclogae geologicae Helvetiae 99, 157-174.

Bollinger, D., 1988. Die Entwicklung des distalen osthelvetischen Schelfs im Barremian und Früh-Aptian: Drusberg-, Mittagspitz- und Schrattenkalk-Formation im Vorarlberg und Allgäu. PhD Thesis, University Zürich, Switzerland, 136 pp.

Bralower, T. Cobabe, E, Clement, B., Sliter, W.V Osburn, C.L, Longoria, J., 1999. The record of global change in mid-Cretaceous (Barremian-Albian) sections from the Sierra Madre, northeastern Mexico. Journal of Foraminiferal Research 29, 418-437.

Bréhéret, J.G., 1997. L'Aptien et l'Albien de la fosse vocontienne (des bordures au bassin). Evolution de la sédimentation et enseignements sur les événements anoxiques. Publication de la Société Géologique du Nord, vol. 25. 164 pp.
Courtillot, V.E., Renne, P.R., 2003. On the age of flood basalt events. Comptes Rendus Geoscience 335, 113-140.

Delamette, M., 1981. Sur la découverte de stromatolithes circalittoraux dans la partie moyen du Crétacé nordsubalpin (Alpes occidentales françaises). Comptes rendus de l'Academie de Sciences à Paris 292, 761-764.

Delamette, M., 1988. L'Evolution du domaine helvétique (entre Bauges et Morcles) de l'Aptien supérieur au Turonien: séries condensées, phosphorites, et circulations océaniques. Publication du Departement de Géologie et Paléontologie, vol. 5. Université de Genève. 316 pp.

Delamette, M. Charollais, J., Decrouez, D., Caron, M., 1997. Les grès verts helvétiques (Aptien moyen - Albien supérieur) de Haute-Savoie, Valais et Vaud (Alpes occidentales franco-suisses). Publications du Département de la Géologie et Paléontologie, vol. 23. Université Genève. 400 pp.

Erba, E., 1994. Nannofossils and "superplumes": the Early Aptian Nannoconid crisis. Paleoceanography 3, 483-501.

Föllmi, K.B., 1981. Sedimentäre Hinweise auf oberkretazische Tektonik im Vorarlberger Helvetikum. Eclogae geologicae Helvetiae 74, 175-187.

Föllmi, K.B., 1986. Die Garschella- und Seewer Kalk-Formation (Aptian-Santonian) im Vorarlberger Helvetikum und Ultrahelvetikum. Mitteilungen aus dem Geologischen Institut der ETH und der Universität Zürich, Neue Folge, vol. 262. 391 pp.

Föllmi, K.B., 1989. Evolution of the Mid-Cretaceous triad: platform carbonates, phosphatic sediments, and pelagic carbonates along the northern Tethys margin. Lecture Notes in Earth Sciences, vol. 23. Springer Verlag, Berlin. 153 pp.

Föllmi, K.B., 1990. Condensation and phosphogenesis: example of the Helvetic MidCretaceous (northern Tethyan Margin). In: Notholt, A.J.G., Jarvis, I. (Eds.) Phosphorite Research and Development. Special Publication, vol. 52. Geological Society, London, pp. 237-252.

Föllmi, K.B., 1996. The phosphorus cycle, phosphogenesis, and marine phosphate-rich deposits. Earth-Science Reviews 40, 55-124.

Föllmi, K.B., Delamette, M., 1991. Comment on: model simulation of mid-Cretaceous ocean circulation. Science 251, 94.

Föllmi, K.B., Ouwehand, P.J., 1987. Die Garschella-Formation und Götzis-Schichten (Aptian-Coniacian): Neue stratigraphische Daten aus dem Helvetikum der Ostschweiz und des Vorarlbergs. Eclogae geologicae Helvetiae 80, 141-191.

Föllmi, K.B., Weissert, H., Bisping, M., Funk, H., 1994. Phosphogenesis, carbon-isotope stratigraphy, and carbonate-platform evolution along the Lower Cretaceous northern tethyan margin. Geological Society of America, Bulletin 106, 729-746.

Föllmi, K.B., Godet, A., Bodin, S., Linder, P., 2006. Interactions between environmental change and shallow-water carbonate build-up along the northern Tethyan margin and their impact on the Early Cretaceous carbon-isotope record. Paleoceanography 21. doi:10.1029/2006PA001313.

Föllmi, K.B., Bodin, S., Godet, A., Linder, P., van de Schootbrugge, B., 2007. Unlocking paleo-environmental information from Early Cretaceous shelf sediments in the Helvetic Alps: stratigraphy is the key! Swiss Journal of Geosciences 100, 349-369.

Funk, H.P., Föllmi, K.B., Mohr, H., 1993. Evolution of the Tithonian-Aptian carbonate platform along the northern Tethyan margin, eastern Helvetic Alps. In: Simo, T. Scott, R.W., Masse, J.-P. (Eds.), Atlas of Cretaceous Carbonate Platforms, vol. 56. American Association of Petroleum Geologists, pp. 387-407. Special Volume.

Gainon, F., 2001. Etude géologique dans la region du Rawil: Cartographie et étude stratigraphique et sédimentologique des Couches à Orbitolines supérieures et de la Formation de Garschella. Diploma Thesis, University of Neuchâtel, Switzerland, 90 pp.

Godet, A., Bodin, S., Föllmi, K.B., Vermeulen, J., Gardin, S., Fiet, N., Adatte, T., Zsolt, B. Stüben, D., van de Schootbrugge, B., 2006. Evolution of the marine stable carbonisotope record during the Early Cretaceous: a focus on the Late Hauterivian and Barremian in the Tethyan realm. Earth and Planetary Science Letters 242 254-271.

Godet, A., Bodin, S., Adatte, T., Vermeulen, J., Föllmi, K.B., (submitted for publication). Clay mineral assemblages along the northern Tethyan margin during the Late Hauterivian-Early Aptian: interactions between climate change and carbonate platform evolution. Cretaceous Research.

Golonka, J., 2004. Plate tectonic evolution of the southern margin of Eurasia in the Mesozoic and Cenozoic. Tectonophysics 381, 235-273.

Gradstein, F.M., Ogg, J.G., Smith, A.G., 2004. A Geologic Time Scale 2004. Cambridge University Press, New York. 600 pp.

Gröcke, D.R., Hesselbo, S.P., Jenkyns, H.C., 1999. Carbon-isotope composition of lower Cretaceous fossil wood: ocean-atmosphere chemistry and relation to sea-level change. Geology 27, 155-158.

Haq, B.U., Hardenbol, J., Vail, P.R., 1987. Chronology of fluctuating sea level since the Triassic. Science 235, 1156-1167.

Heim, A., 1934. Stratigraphische Kondensation. Eclogae geologicae Helvetiae 27, 372-383.

Heim, A., Seitz, O., 1934. Die mittlere Kreide in den helvetischen Alpen von Rheintal und Vorarlberg und das Problem der Kondensation. Denkschriften der Schweizerischen Naturforschenden Gesellschaft 69, 185-310.

Herrle, J.O., Kößler, P., Friedrich, O., Erlenkeuser, H. Hemleben, C. 2004. High-resolution carbon isotope records of the Aptian to Lower Albian from SE France and the Mazagan Plateau (DSDP Site 545): a stratigraphic tool for paleoceanographic and paleobiologic reconstruction. Earth and Planetary Science Letters 218, 149-161.

Hillgärtner, H., van Buchem, F.S.P., Gaumet, F., Razin, P., Pittet, B., Grötsch, J., Droste, H. 2003. The Barremian-Aptian evolution of the eastern Arabian carbonate platform margin (northern Oman). Journal of Sedimentary Research 73, 756-773.

Immenhauser, A., Hillgärtner, H., Sattler, U., Bertotti, G., Schoepfer, P., Homewood, P., Vahrenkamp, V., Steuber, T., Masse, J.P., Droste, H., Taal-van Koppen, J., van der Kooij, B., van Bentum, E., Verwer, K., Hoogerduijn Strating, E., Swinkels, W., Peters, J., Immenhauser-Potthast, I., Al Maskery, S., 2004. Barremian-lower Aptian Qishn 
Formation, Haushi-Hufq area, Oman: a new outcrop analogue for the Kharaib/ Shu'aiba reservoirs. GeoArabia 9, 153-194.

Immenhauser, A., Hillgärtner, H., van Bentum, E., 2005. Microbial-foraminiferal episodes in the Early Aptian of the southern Tethyan margin: ecological significance and possible relation to oceanic anoxic event 1a. Sedimentology 52, 77-99.

Jenkyns, H.C., 1980. Cretaceous oceanic anoxic events: from continents to oceans. Journal of the Geological Society 137, 171-188.

Kuhn, O., 1996. Geochemie und Paläozeanographie der phosphatführenden Gemsmättli-Schicht, Valanginian, Helvetikum der Nordalpen. PhD Thesis, ETH Zürich, Switzerland, $380 \mathrm{pp}$.

Kuhnt, W., Moullade, M., Masse, J.-P., Erlenkeuser, H., 1998. Carbon isotope stratigraphy of the lower Aptian historical stratotype at Cassis-La Bédoule (SE France). Géologie Méditerranéenne 25, 63-79.

Larson, R.L., 1991. The latest pulse of the Earth: evidence for a mid-Cretaceous superplume. Geology 19, 547-550.

Leckie, R.M., Bralower, T.J., Cashman, R., 2002. Oceanic anoxic events and plankton evolution: biotic response to tectonic forcing during the mid-Cretaceous. Paleoceanography 17. doi:10.1029/2001 pa000623.

Lehmann, C., Osleger, D.A., Montanez, I.P., Arnaud-Vanneau, A., Banner, J., 1999. Evolution of Cupido and Coahuila carbonate platforms, Early Cretaceous, northeastern Mexico. Geological Society of America Bulletin 111, 1010-1029.

Lienert, O., 1965. Stratigraphie der Drusbergschichten und des Schrattenkalks im Säntisgebirge unter besonderer Berücksichtigung der Orbitoliniden. PhD Thesis, ETH Zürich, Switzerland, 141 pp.

Linder, P., Gigandet, J., Hüsser, J.-L., Gainon, F., Föllmi, K.B., 2006. The Early Aptian Grünten Member: description of a new lithostratigraphic unit of the Helvetic Garschella Formation. Eclogae geologicae Helvetiae 99, 327-341.

Lugeon, M., 1918. Les hautes Alpes calcaires entre la Lizerne et la Kander (Wildhorn, Wildstrubel, Balmhorn et Torrenthorn), Fascicule 3. Matériaux pour la Carte géologique de la Suisse, nouvelle série 30, 207-360.

Masse, J.-P., 1993. Valanginian-Early Aptian carbonate platforms from Provence, southeastern France. In: Simo, T., Scott, R.W., Masse, J.-P.(Eds.), Atlas of Cretaceous Carbonate Platforms, vol. 56. American Association of Petroleum Geologists, pp. 363-374. Special Volume.

Masse, J.-P., El Albani, A., Erlenkeuser, H., 1999. Stratigraphie isotopique $\left(\delta^{13} \mathrm{C}\right) \mathrm{de}$ l'Aptien inférieur de Provence (SE France): application aux correlations plateforme/basin. Eclogae geologicae Helvetiae 92, 259-263.

Menegatti, A.P., Weissert, H., Brown, R.S., Tyson, R.V., Farrimond, P., Strasser, A., Caron, M., 1998. High-resolution $\delta^{13} \mathrm{C}$ stratigraphy through the Early Aptian "Livello Selli" of the Alpine Tethys. Paleoceanography 13, 530-545.

Menkfeld-Gfeller, U., 1995. Stratigraphie, Fazies und Paläogeographie des Eocaens der helvetischen Decken der Westschweiz (Diablerets- und Wildhorn-Decke). Eclogae geologicae Helvetiae 88, 115-134.

Menkfeld-Gfeller, U., 1997. Die Bürgen-Formation und die Klimsenhorn-Formation: Formelle Definition zweier lithostratigraphischen Einheiten des Eozäns der helvetischen Decken. Eclogae geologicae Helvetiae 90, 245-261.

Michalik, J., 1994. Lower Cretaceous carbonate platform facies, Western Carpathians. Palaeogeography, Palaeoclimatology, Palaeoecology 111, 263-277.

Moullade, M., Kuhnt, W., Bergen, J.A., Masse, J.P., Tronchetti, G., 1998. Correlation of biostratigraphic and stable isotope events in the Aptian historical stratotype of La
Bedoule (southeast France). Comptes Rendus de l'Académie de Sciences - Series IIA - Earth Planetary Sciences 327, 693-698.

Ouwehand, P.J., 1987. Die Garschella-Formation ("Helvetischer Gault", Aptian-Cenomanian) der Churfirsten-Alvier Region (Ostschweiz). Mitteillungen aus dem geologischen Institut der ETH und der Universität Zürich, Neue Folge, vol. 275. 296 pp.

Pittet, B., van Buchem, F.S.P., Hillgärtner, H., Razin, P., Grötsch, J., Droste, H., 2002. Ecological succession, palaeoenvironmental change, and depositional sequences of Barremian-Aptian shallow-water carbonates in northern Oman. Sedimentology 49, $555-581$.

Reitner, J., Föllmi, K.B., 1991. A new "deep-water" Chaetetopsis species (Chaetetopsis favositiformis n. sp., Demospongiae) from the Plattenwald Bed (Mid-Cretaceous Garschella Formation, Vorarlberg, Austria). Eclogae geologicae Helvetiae 84, 837-849.

Schaub, H.P., 1936. Geologie des Rawilgebietes. Eclogae geologicae Helvetiae 29, 337-407.

Schaub, H.P., 1948. Über Aufarbeitung und Kondensation. Eclogae geologicae Helvetiae 41, 89-94.

Schenk, K., 1992. Die Drusberg- und Schrattenkalk-Formation (Unterkreide) im Helvetikum des Berner Oberlandes. PhD Thesis, University of Berne, Switzerland, 180 pp.

Schlager, W., Philip, J., 1990. Cretaceous carbonate platforms. In: Ginsburg, R.N., Beaudoin, B. (Eds.), Cretaceous Resources, Events and Rhythms. Kluwer Academic Publishers, Dordrecht, pp. 173-195.

Schlanger, S.O., Jenkyns, H.C., 1976. Cretaceous oceanic anoxic events: causes and consequences. Geologie en Mijnbouw 55, 179-184.

Stacher, P., 1980. Stratigraphie, Mikrofazies und Mikropaläontologie der WangFormation. Beiträge zur geologischen Karte der Schweiz, N.F., vol. 152. 105 pp.

Stampfli, G.M., Borel, G.D., 2002. A plate tectonic model for the Paleozoic and Mesozoic constrained by dynamic plate boundaries and restored synthetic oceanic isochrons. Earth and Planetary Science Letters 196, 17-33.

Taylor, B., 2006. The single largest oceanic plateau: Ontong Java-Manihiki-Hikurangi. Earth and Planetary Science Letters 241, 372-380.

Van de Schootbrugge, B., 2001. Influence of paleo-environmental changes during the Hauterivian (Early Cretaceous) on carbonate deposition along the northern margin of the Tethys: EVIDENCE from geochemical records (C-, O-, Sr-isotopes, P, Fe, Mn). $\mathrm{PhD}$ Thesis, University of Neuchâtel, Switzerland, $268 \mathrm{pp}$.

Van de Schootbrugge, B., Kuhn, O., Adatte, T., Steinmann, P., Föllmi, K.B., 2003. Decoupling of $\mathrm{P}$ - and $\mathrm{C}_{\mathrm{org}}$-burial following Early Cretaceous (ValanginianHauterivian) platform drowning along the NW Tethyan margin. Palaeogeography, Palaeoclimatology, Palaeoecology 199, 315-331.

Weissert, $\mathrm{H}$., Erba, E., 2004. Volcanism, $\mathrm{CO}_{2}$ and palaeoclimate: a Late Jurassic-Early Cretaceous carbon and oxygen isotope record. Journal of the Geological Society of London 161, 695-702.

Wissler, L., Funk, H., Weissert, H., 2003. Response of Early Cretaceous carbonate platforms to changes in atmospheric carbon dioxide levels. Palaeogeography, Palaeoclimatology, Palaeoecology 200, 187-205. 